\author{
Diana Sorić \\ Teuta Serreqi Jurić ${ }^{* *}$
}

\title{
The Textual Transmission of Iter Buda Hadrianopolim, a Travelogue by Antun Vrančić
}

Croatian humanist, diplomat, and prelate Antun Vrančić (1504-1573) produced a number of literary works, among which the travelogue Iter Buda Hadrianopolim holds a special place, since it was written as a testimony of Vrančić's first mission to Constantinople (1553-1557), on which he was sent by order of Emperor Ferdinand I (15031564). The text is preserved in the form of Vrančić's autograph and three transcripts as part of the geographical and historical work De Illyrico Caesaribusque Illyricis by Croatian humanist Ivan Tomko Mrnavić (1580-1637), and was published twice, in the $18^{\text {th }}$ and $19^{\text {th }}$ centuries. This paper provides an insight into the textual transmission of the Iter Buda Hadrianopolim based on the findings the authors arrived at while preparing a critical edition of this text by Vrančić. A philological comparison of Vrančić's manuscript and the preserved transcripts provides an answer to the question which copy is closest to Vrančićs original, while a comparison of the manuscript and editions indicates that the existing editions are unreliable for linguistic, stylistic, or historiographical research due to errors which hinder the correct reading of the text. This, along with the fact that no critical edition of the text exists, is why a new philological treatment of this text by Vrančić according to the principles of modern neo-Latin studies was necessary.

Keywords: Antun Vrančić, Iter Buda Hadrianopolim, travelogue, humanism, textual transmission

Diana Sorić, Department of Classical Philology, University of Zadar, Obala kralja Petra Krešimira IV. 2, 23000 Zadar, Croatia, E-mail: diana.soric@unizd.hr

** Teuta Serreqi Jurić, Department of Classical Philology, University of Zadar, Obala kralja Petra Krešimira IV. 2, 23000 Zadar, Croatia, E-mail: tserreqi@unizd.hr 


\section{Introduction}

Antun Vrančić from Šibenik (1504-1573) was a Croatian humanist who left an indelible mark not only in the history of the Croatian-Hungarian Kingdom in the $16^{\text {th }}$ century, but also in Croatian literature written in Latin. He built a rich ecclesiastical and diplomatic career at the courts of King John Zápolya (14871540), King and Emperor Ferdinand I (1503-1564), and his successor Maximilian II (1527-1576), witnessing some of the most important events for the Croatian-Hungarian Kingdom in that period. He received some of the highest honours at the time - Maximilian awarded him the title of Primate of the Hungarian Church in 1569 and appointed him Regent of Hungary in June 1572. ${ }^{1}$ Vrančić played such a prominent role in the history of Croatian humanism primarily owing to the impressive collection of approximately a thousand letters (composed mostly in Latin and to a lesser extent in Italian and Hungarian) along with other completed or unfinished works, i.e. those which have been preserved in full or in fragments. ${ }^{2}$

\footnotetext{
1 The most comprehensive insight into Vrančić's life so far has been provided by the only Croatian monograph on this subject: Darko Novaković, Vladimir Vratović, S visina sve. Antun Vrančić (Zagreb: Globus, 1979). Cf. also: Alberto Fortis, Viaggio in Dalmazia, I (Venezia: Presso Alvise Milocco all'Apolline, 1774), 137-145; Šime Ljubić, Dizionario biografico degli uomini illustri della Dalmazia (Vienna-Zara: Rod. Lechner; Battara e Abelich, 1856), 305-308; Federico Antonio Galvani, Il re d'armi di Sebenico con illustrazioni storiche, I (Venezia: Prem. Stabil. Tip. di Pietro Naratovich, 1884), 215-219; Ivan Kukuljević Sakcinski, Glasoviti Hrvati prošlih vjekova. Niz životopisâ (Zagreb: Naklada Matice hrvatske, 1886), 41-72; Krsto Stošić, Galerija uglednih Šibenčana (Šibenik: Tiskara Kačić, 1936), 94-96; Marianna Daisy Birnbaum, Croatian and Hungarian Latinity in the Sixteenth Century (Zagreb-Dubrovnik: Most, 1993), 270-306; Darko Novaković, Sentimentalni odgoj. Antun i Faust Vrančić (Šibenik: Gradska knjižnica "Juraj Šižgorić”, 1995), 5-16, 94-109; Šime Demo, Castilia Manea-Grgin, eds., Antun Vrančić. Historiografski fragmenti (Šibenik: Gradska knjižnica "Juraj Šižgorić”, 2014), 7-20; Éva Gyulai, "Antonius Verantius", in: Christian-Muslim Relations: A Bibliographical History, vol. 7, ed. David Thomas et al. (Leiden: Brill, 2015), 362-371; Zrinka Blažević, Anđelko Vlašić, eds., Carigradska pisma Antuna Vrančića: hrvatski i engleski prijevod odabranih latinskih pisama (Zagreb-Istanbul: Oğuz Aydemir, 2018), 28-63.

2 Vrančićs oeuvre includes two collections of poetry (Otia and the lost Elegiae), two speeches (a speech given at the wedding of the Polish Prince Sigismund Augustus, brother of Queen Isabella Zápolya, in 1543, and a speech given on the occasion of the coronation of Rudolf II Habsburg as the King of Hungary in 1572), a prayer (the only surviving text by Vrančić in Croatian), historiographical texts (a series of larger or smaller fragments and unfinished writings of historical nature), reports from his Ottoman missions (the travelogue Iter Buda Hadrianopolim, written on the occasion of Vrančićs first mission to Constantinople, 1553 - 1557, and a text written in the form of a journal chronicling his trip to Constantinople on his second mission, 1567 - 1568), biographies of Juraj Utišenić and Šimun Dijak Voćinski, and his correspondence, the most important in terms of literary value (791 sent and 139 received letters, with 199 letters co-authored with other envoys - figures according to Diana Sorić, "Klasifikacija pisama Antuna Vrančića", Colloquia Maruliana 18 (2009), 98). For more details on Vrančićs literary oeuvre, see: Birnbaum, Croatian and Hungarian Latinity, 270-306; Demo, Manea-Grgin, Historiografski fragmenti, 20-69; Diana Sorić, Teuta Serreqi Jurić, eds., Antun Vrančić: Epistolae ad familiares (Zadar: Sveučilište u Zadru, 2020), XVII-XXVII, and the literature cited in the notes therein.
} 
Vrančićs travelogue Iter Buda Hadrianopolim is also one of his unfinished works, and it was written as a testimony of his first diplomatic mission to Constantinople (1553-1557) by order of the Habsburg Emperor Ferdinand I. ${ }^{3}$ The experienced diplomat Antun Vrančić and the diplomat and commander of the Danube Naval Flotilla Ferenc Zay, accompanied by about sixty men, set out for the Ottoman capital from Buda on 25 July 1553 with the task of concluding a Habsburg-Ottoman peace treaty with Sultan Suleiman the Magnificent and liberating the Habsburg envoy Giovanni Maria Malvezzi. It was estimated that the mission would be completed by November 1553, but due to various aggravating circumstances it lasted until August 1557, and the desired objective was not fully achieved. The envoys succeeded in obtaining freedom for the imprisoned Malvezzi, but not in persuading the Ottomans to give up Transylvania. ${ }^{4}$ Still, maintaining the status quo was also considered a success, which is why Ferdinand rewarded Vrančić on his return from Constantinople by granting him the position of Bishop of Eger, which was the second highest rank in the Hungarian ecclesiastical hierarchy, immediately after the Archbishop of Esztergom. ${ }^{5}$

The thirty-day journey started on the Danube from Buda to Belgrade and continued by land to Smederevo, then further south along the Morava valley to Niš and through Sofia and Drinopolje (ancient Hadrianopolis, Turkish Edirne) to Constantinople, where the envoys arrived on 25 August 1553. Vrančić described the individual legs of the journey and what he had experienced in his report or travelogue, enriching the story with factual data and many historical, geographical,

3 For more details on this work by Vrančić, see Petar Matković, "Putovanja po balkanskom poluotoku XVI. vieka. Putovanje A. Vrančića g. 1553. u Carigrad”, Rad JAZU 71 (1884), 1-60. On the literary aspects of the travelogue Iter Buda Hadrianopolim, see Diana Sorić, Teuta Serreqi Jurić, "Literary Aspects of Antun Vrančićs Travelogue Iter Buda Hadrianopolim,” Živa Antika 68 (2018): 153-168.

4 After the first meeting with Suleiman and the unsuccessful negotiations on the issue of Transylvania, the Sultan travelled to Asia Minor, where he started a war against the Persians while the envoys continued the negotiations with Rüstem Pasha. Vrančić and Zay sent Malvezzi to Ferdinand in Vienna to obtain new instructions. Their stay in Constantinople was unexpectedly extended because a military revolt against Suleiman broke out under the leadership of his eldest son Mustafa. In January 1555, the envoys learned that Malvezzi would not be returning from Vienna, but that Ferdinand was sending the Flemish humanist Augier Ghislain de Busbecq (1522-1592) as negotiator instead. After Suleiman's messenger announced that the Sultan would receive the three Habsburg envoys at his court in Amasya (ancient Amasia), the envoys left Constantinople for Asia Minor and arrived in Amasya on 7 April. The road to Amasya led through Ankara, where the deputies arrived after 19 days of travel, on 28 March to be precise. The next day (29 March 1555), while touring the city, they discovered a Roman building with a carved copy of the inscription Res gestae divi Augusti or Monumentum Ancyranum (according to Bratislav Lučin, "Antun Vrančić i Monumentum Ancyranum", Prilozi povijesti umjetnosti u Dalmaciji 45 (2019), No. 1, 228, 230). On Vrančićs important and hitherto unjustly neglected role in finding and transcribing this famous inscription, see the quoted title.

5 The peace treaty was negotiated by Busbecq and the final agreement was signed on 1 June 1562 . For more details on Vrančić's first mission to Constantinople, see Blažević, Vlašić, Carigradska pisma, 3555. Cf. also: Novaković, Vratović, S visina sve, 115-119, 132-136; Birnbaum, Croatian and Hungarian Latinity, 281-291; Lučin, "AntunVrančić", 224-230. 
and ethnographic details. The travelogue ends abruptly and unexpectedly when the envoys arrive in Drinopolje on 19 August: Et mox civitas Hadrianopolis... (“A little later we come to the town of Drinopolje..."). Assuming that Vrančić described the rest of the journey as well, the fate of the second part of his travel diary remains unclear. ${ }^{6}$

Despite the tireless efforts of a small community of classical philologists in Croatia, the situation in the study of our national Latin heritage is such that valuable texts, even entire oeuvres of individual authors, remain unpublished or are in dire need of new editions prepared according to the principles of contemporary neo-Latin studies. Such is also the case with the literary legacy of Antun Vrančić, which was last published in the famous edition by the Hungarian Academy of Sciences Monumenta Hungariae historica - Scriptores. ${ }^{7}$ Therefore, any endeavour made in this field, no matter how small, is certainly valuable. In this context, the purpose of this paper is to provide insight into the textual transmission of Vrančićs travelogue Iter Buda Hadrianopolim based on a philological comparison of the manuscripts (the autograph and the transcripts) and the published editions in order to point out that the existing editions are not sufficiently reliable for linguistic and stylistic or historiographical research and that a real need exists for Vrančić's work to be published in accordance with modern philological criteria. $^{8}$

\section{Manuscripts and editions}

As for the manuscripts of Vrančićs travelogue, one autograph and three transcripts survive. The autograph is stored in the Széchényi National Library in Budapest under the call numbers Fol. Lat. 2380, III, ff. 81-112v (the first part of the manuscript) and Fol. Lat. 422, II, ff. 76-99 (the second part of the manuscript).

\footnotetext{
6 The only indication of this in literature can be found in A. Fortis (Viaggio, I, 141, note a), who claims that that part of the record of this journey was taken by Jesuit Filippo Riceputi so he could use it to compile his work Illiricum [sic] Sacrum and that it was irretrievably lost.

7 László Szalay, Gusztáv Wenzel, eds., Monumenta Hungariae historica. Scriptores - Verancsics Antal, Összes munkái, vol. 1-12 (Budapest: Eggenberger, 1857-1875).

8 As the first in a series of modern critical editions of Vrančićs texts, the recently published family correspondence of Antun Vrančić should be mentioned: Sorić, Serreqi Jurić, Antun Vrančić: Epistolae ad familiares. As for Vrančić's travelogue Iter Buda Hadrianopolim, the authors have conducted preliminary research on the manuscript and are currently preparing a critical edition.
} 


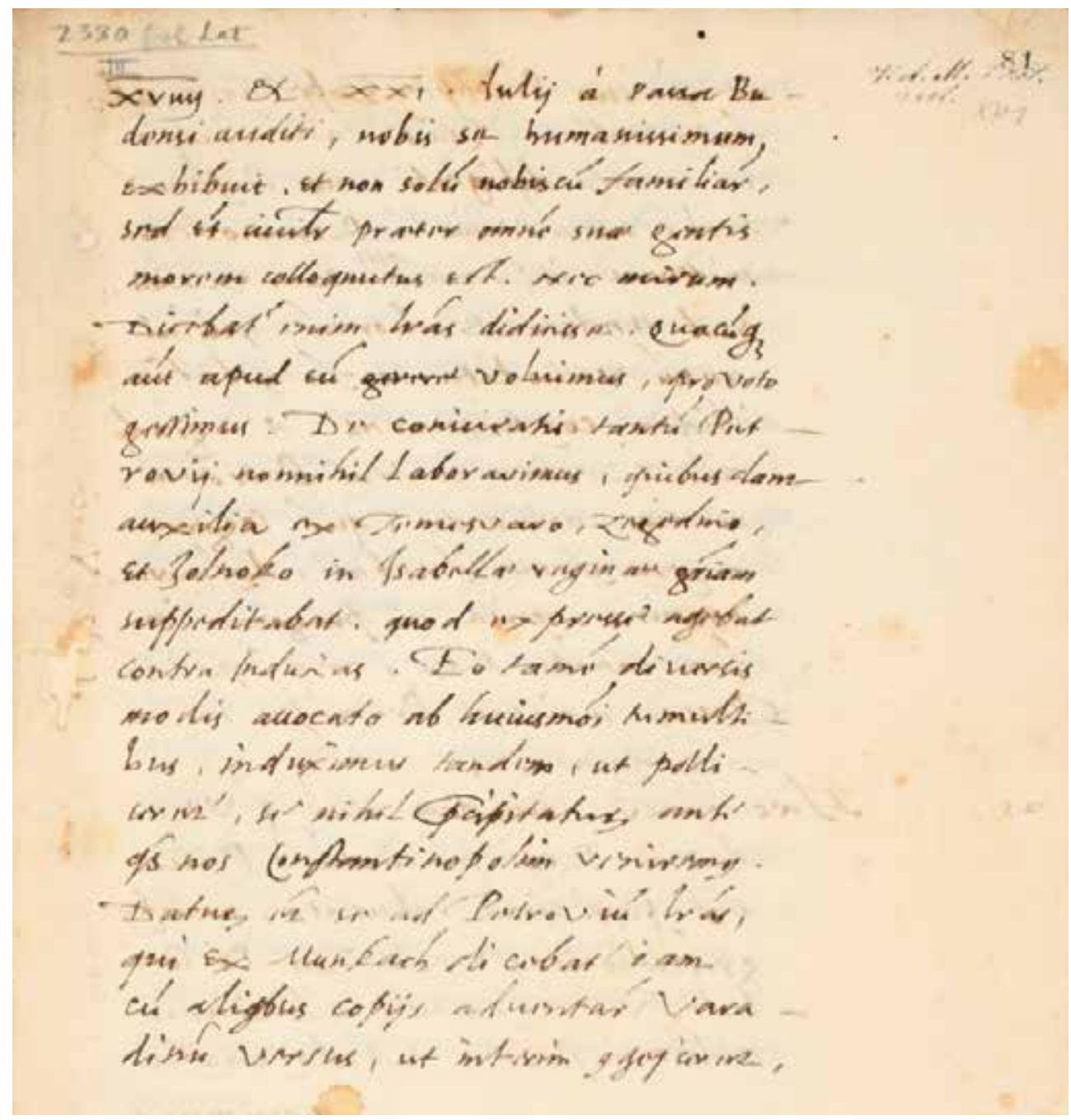

Picture 1. A folio from Vrančićs autograph: $B 81$

In addition to the autograph, a large part of Vrančićs travelogue has been preserved in the transcript contained in the second book of the geographical and historical work De Illyrico Caesaribusque Illyricis dialogorum libri septem by Croatian humanist Ivan Tomko Mrnavić (1580-1637). Although Mrnavićs manuscript was once considered lost, today we can reliably speak about three copies. One is kept in the National Museum of Bosnia and Herzegovina in Sarajevo (call no. E-541), one in the National and University Library in Zagreb (call no. R 7195), and one in the Franciscan monastery in Dubrovnik. ${ }^{9}$

9 As for the Dubrovnik manuscript, it actually consists of two texts entitled Prodromon et una generalis Illyrici descriptio and Caesares Illyrici stored in the collection of Ignjat Đurđević Rerum Il- 


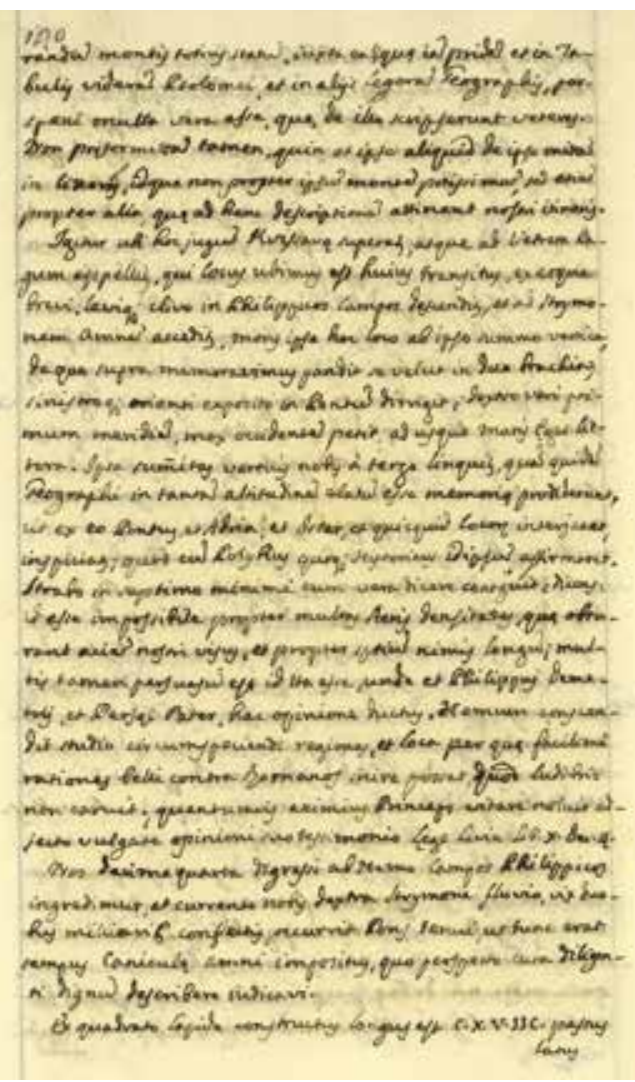

Picture 2. A page from the Zagreb manuscript: $Z 140$

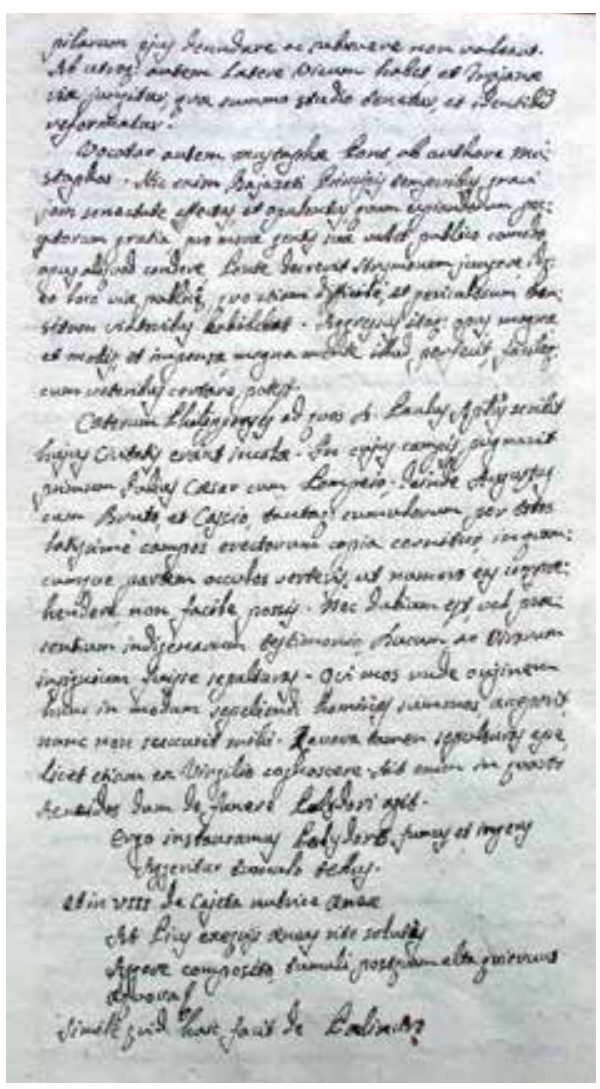

Picture 3. A folio from the Sarajevo manuscript: $S 89 \mathrm{v}$

According to the research conducted so far, the oldest manuscript is the one from Dubrovnik, which was found to have been transcribed by Mrnavić's good friend Rafael Levaković (c. 1590 - c. 1649). The Zagreb transcript (transcribed by one person) and the Sarajevo transcript (transcribed by several people, whereby most of the text was transcribed by the person who transcribed the Zagreb copy) were copied from the same template and can be dated to the late $18^{\text {th }}$ or early $19^{\text {th }}$ century, according to the marginal notes made by Alberto Fortis. The Dubrovnik manuscript, although it largely matches the Zagreb and Sarajevo manuscripts, is a shortened version, basically a summary of the first two manuscripts; however, it also contains parts that cannot be found in the Zagreb and Sarajevo copies. It

lyricarum sive historiae Rhacusanae. Cf. Tamara Tvrtković, "Marko Marulić u djelu Ivana Tomka Mrnavića", Colloquia Maruliana 16 (2007), 295-297, and Tamara Tvrtković, Između znanosti i bajke - Ivan Tomko Mrnavić (Zagreb-Šibenik: Hrvatski institut za povijest; Gradska knjižnica "Juraj Šižgorić", 2008), 48-52, 87. We would like to thank our colleague Tamara Tvrković for granting us access to the manuscripts. 
is assumed that the transcriber made the Dubrovnik compendium on the basis of a hitherto unknown source (an autograph?), which could have served as a source for both the Zagreb and the Sarajevo transcripts. ${ }^{10}$

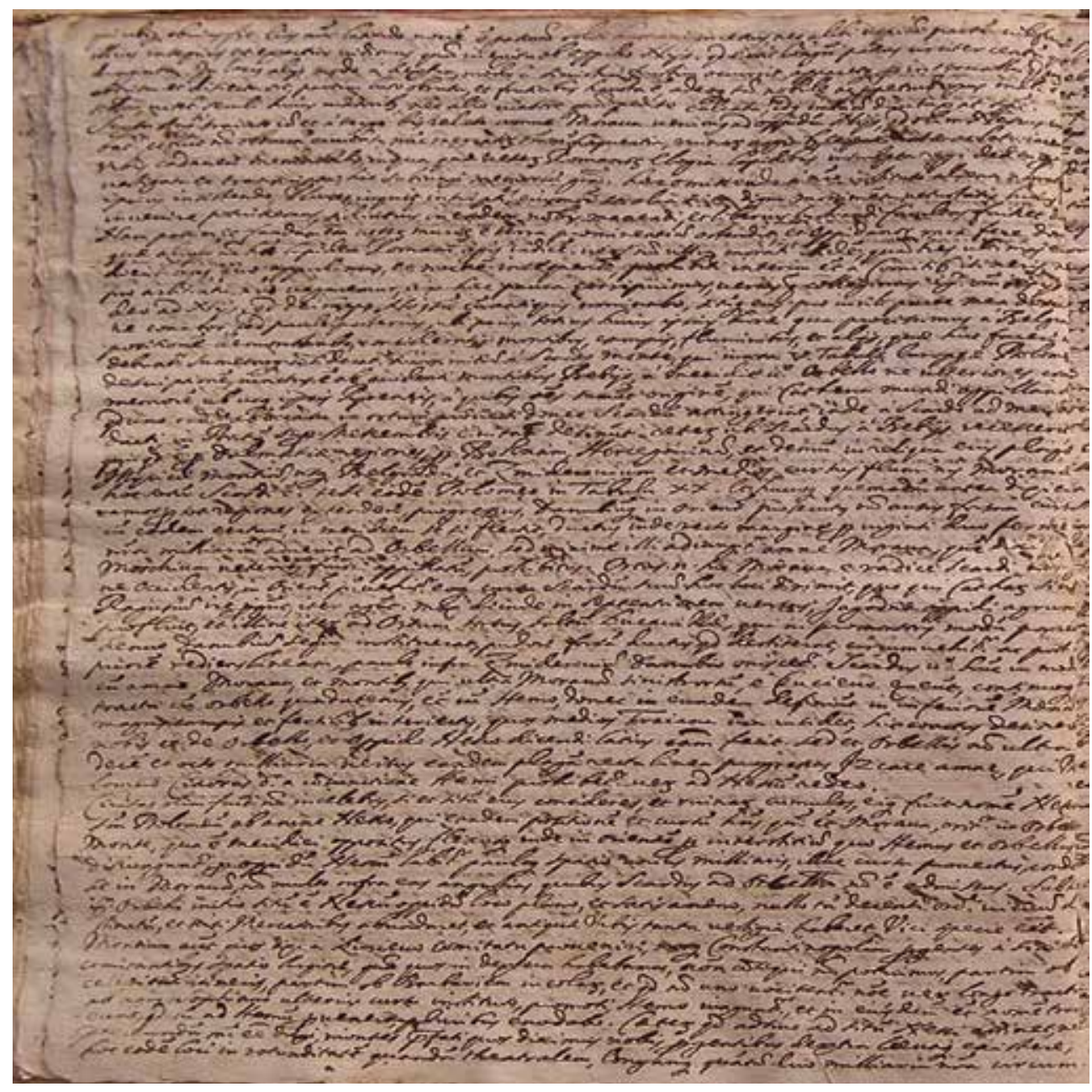

Picture 4. A folio from the Dubrovnik manuscript: D 25v

As for the published versions, Vrančićs text was first published in its entirety in the work of the Italian travelogue writer Alberto Fortis Viaggio in Dalmazia, as an appendix between the first and the second volumes in $1774,{ }^{11}$ and the second

10 Cf. Tvrtković, "Marko Marulić", 295-297, and Tvrtković, Između znanosti i bajke, 53-77, 87. For more details on Mrnavić and his book De Illyrico Caesaribusque Illyricis, see the previously quoted title.

11 Alberto Fortis, Viaggio in Dalmazia, I-II (Venezia: Presso Alvise Milocco all'Apolline, 1774), V-XLVII. 
time in the first volume of the Hungarian edition Monumenta Hungariae historica - Scriptores in 1857. ${ }^{12}$ A small part of the travelogue can also be found in the fifth volume of József Koller's Historia episcopatus Quinqueecclesiensis. ${ }^{13}$ The Croatian translation of Vrančić's travelogue, done by Darko Novaković, can be found in the translated edition of Fortis's Put po Dalmaciji. ${ }^{14}$

\section{Comparing the autograph and the transcripts}

As we have already stated, Vrančić's travelogue is cited within the second book of Mrnavićs text De Illyrico Caesaribusque Illyricis as part of the description of the province of Dardania, but not in its entirety. Mrnavić omits the very beginning of the travelogue (autograph Fol. Lat. 2380, III, ff. 81-82) and starts the text with Vrančićs departure from Buda on 26 July and his arrival in Tolna: Die, inquit, 26. Buda digressi, naves ingressi primo noctis crepusculo Tolnam venimus... ${ }^{15}$ The leg of the journey from Buda to Belgrade, i.e. from 26 July to 1 August (autograph Fol. Lat. 2380, III, ff. 82-92v) is condensed, and then Vrančićs text is faithfully rendered from the moment the envoys left Belgrade on 1 August and travelled by land towards Smederevo: At prima die Augusti, relictis in portu ad Belgradum navibus... ${ }^{16}$ Mrnavić also leaves out the part of Vrančićs text which lists the Roman inscriptions on stone monuments near Niš (autograph Fol. Lat. 2380, III, pp. 102-103v). ${ }^{17}$

Although priority should undoubtedly be given to the autograph of the Iter Buda Hadrianopolim over its transcripts, it seemed opportune to investigate the relationship between Vrančićs autograph and the three transcripts of Mrnavićs text to see which of the manuscripts is closest to Vrančićs original and what the hitherto unknown template on the basis of which the transcripts of De Illyrico Caesaribusque Illyricis were made might have looked like, at least as far as the part relating to Vrančić's travelogue is concerned. ${ }^{18}$ As can be seen from Table 1 in the appendix, the philological comparison of the manuscripts shows

\footnotetext{
12 László Szalay, ed., Verancsics Antal. Összes munkái, vol. 1 (= Monumenta Hungariae historica. Scriptores II) (Budapest: Eggenberger, 1857), 288-334.

13 József Koller, ed., Historia episcopatus Quinqueecclesiensis, V (Posonii et Pestini: Sumptibus Joannis Michaelis Landerer, 1782-1784), 340-344.

14 Antun Vrančić, "Putovanje iz Budima u Drinopolje”, in: Alberto Fortis, Put po Dalmaciji, ed. Josip Bratulić, trans. Mate Maras and Darko Novaković (Split: Marjan tisak, 2004), 115-145.

${ }^{15}$ Cf. Hrvatska (hereafter: HR) - Nacionalna i sveučilišna knjižnica u Zagrebu (hereafter: NSK) - R 7195, p. 118.

16 Cf. HR-NSK-R 7195, p. 121.

17 Cf. Tvrtković, Između znanosti i bajke, 84-85.

18 In the Zagreb manuscript, Vrančićs travelogue (not including the condensed part) is quoted on pp. 121-151, in the Sarajevo version on ff. 78-92, and in the Dubrovnik version on ff. 24-29.
} 
that in all three transcripts there are many similarities in terms of differences in readings, additions, omissions, and inversions, but the Dubrovnik manuscript is certainly closest to Vrančićs original in that, apart from being the most correct in terms of its Latin, it contains the least number of different readings in relation to the Zagreb and Sarajevo manuscripts, which indicates that the transcriber of the template accurately transcribed Vrančićs autograph in these places. We have noticed about twenty places where the readings differ significantly, and here are just a few interesting examples:

Example 1. In the autograph on f. 108v, the word aurium in the sentence $\mathrm{Ca}$ pitis et colli et aurium monilia perpendenda diligentius ("The chains on the head, neck, and ears should be considered more closely.") is problematic. ${ }^{19}$ In the Dubrovnik manuscript, its form is identical, while in the Zagreb and Sarajevo manuscripts, instead of aurium, the word is navium, which significantly changes the meaning of the sentence, or rather makes the translation meaningless.

Example 2. In the autograph on f. $78 \mathrm{v}$, in the sentence Verum quotannis eo excusso identidem illis reficitur ("But every year after it is demolished [sc. the bridge over the river Iskar], they [sc. the inhabitants of Sofia] rebuild it."), there is an ablative absolute with the participle excusso. ${ }^{20}$ The Dubrovnik manuscript brings it faithfully, while in the Zagreb and Sarajevo manuscripts we find the form discenso.

As far as additions and inversions are concerned, most of such examples appear in all three transcripts, with the Zagreb copy containing the most additions. As for inversions, the Dubrovnik copy contains one which does not appear in the Zagreb and Sarajevo transcripts. When it comes to lacunae, they are also mostly consistent in all three manuscripts, although the Zagreb manuscript again has the greatest number of them. Nevertheless, it should be noted that in the $\mathrm{Du}$ brovnik manuscript there are places where whole phrases are omitted (e.g. the expression ultra Philipopolim on f. 90v in Vrančićs autograph) or even whole sentences (Non tamen a religione Christiana prohibentur on f. 87 of Vrančićs autograph), which have been retained in the Zagreb and Sarajevo manuscripts.

A comparison of the Zagreb and Sarajevo manuscripts shows that the former contains far more differences in relation to Vrančićs autograph, including a much larger number of different readings, additions, lacunae, and inversions than is the case with the Sarajevo transcript. The numerical data related to the deviations between the transcripts are shown in the table below:

\footnotetext{
19 Hungary (hereafter: HU) - Országos Széchényi Könyvtár, Budapest (hereafter: OSZK) - Fol. Lat. 2380, III, fol. $108 \mathrm{v}$.

${ }^{20}$ Hungary (hereafter: HU) - Országos Széchényi Könyvtár, Budapest (hereafter: OSZK) - Fol. Lat. 422 , II, fol. $78 \mathrm{v}$.
} 


\begin{tabular}{|c|c|c|c|}
\hline & $\begin{array}{c}\text { Zagreb } \\
\text { manuscript }\end{array}$ & $\begin{array}{c}\text { Sarajevo } \\
\text { manuscript }\end{array}$ & $\begin{array}{c}\text { Dubrovnik } \\
\text { manuscript }\end{array}$ \\
\hline differences in readings & 158 & 104 & 78 \\
\hline additions & 14 & 10 & 10 \\
\hline omissions & 43 & 31 & 33 \\
\hline inversions & 7 & 6 & 7 \\
\hline
\end{tabular}

\section{Comparing the autograph and the editions}

A philological comparison of the autograph and the two complete editions (Fortis and Szalay) shown in Table 2 leads us to conclude the following: among the deviations from the original, we expectedly find that divergent readings are the largest in number, of which the Fortis edition contains a total of 89 and the Szalay edition markedly fewer, 65 , which would indicate that the Hungarian edition is far more reliable in that respect. In the Fortis edition, frequent differences in the transcription of toponyms, hydronyms, etc. were observed, such as: Erdevod instead of Erdewd in the autograph, Kemzeg instead of Kewzeg, Ulok instead of Illok, Handor instead of Nandor, Sarnovo instead of Sarnow, Czarevo Brod instead of Czarew Brod, Tarnavo instead of Tarnaw, Hormanles instead of Hormanly, Vatren instead of Vethren, Topoliza instead of Topolniza etc.

Even though scholars researching this text by Vrančić can use both editions when it comes to these incorrect readings, challenges arise in places where they both deviate from the autograph. There are several such examples, and they may lead the reader to misunderstand the text, which may in turn result in mistranslation. The following examples illustrate this most aptly:

Example 1. In the autograph, on f. 79v, we find the sentence Hic autem excubiae sic aguntur ("Here guard duty is performed in the following way."). ${ }^{21}$ Fortis transcribes hic with hae, which automatically changes the meaning of the sentence, ${ }^{22}$ while Szalay uses the form haec, which does not fit into the sentence grammatically at all. ${ }^{23}$

Example 2. On the same folio below is the problematic reading of the adverb quoquam in the sentence Viae publicae locum in montibus deligunt eminentius iminentem sic, ut et viam ipsam habeant sub oculis et latissime quoquam versus commode possit prospicere... ("On the hilly part of the road, they chose a higher place so that they would have the road in front of their eyes and easily be able to look out very far in any direction... "). ${ }^{24}$ Fortis transcribes this

\footnotetext{
${ }^{21}$ HU-OSZK-Fol. Lat. 422, II, fol. 79v.

22 Fortis, Viaggio, XXXIII.

${ }^{23}$ MHH 1 (= II), 318.

${ }^{24}$ HU-OSZK-Fol. Lat. 422, II, fol. 79v.
} 
as quaqua, ${ }^{25}$ which does not change the meaning to any significant degree, while in the Hungarian edition we find the form quaque. ${ }^{26}$

Example 3. The last example we will note is on $\mathrm{f} .94 \mathrm{v}$ in the autograph. In the sentence Vectus inde per multos convallium anfractus aliquot locis pro montium sinuationibus dilatatur... ("Passing then through many winding valleys, in several places it [sc. the river Struma] expands before the meandering of the mountains..." ${ }^{27}$ instead of pro in Vrančićs manuscript, in the Fortis edition we find the preposition per $^{28}$ and in Szalay prae. ${ }^{29}$

It should be noted that there are also differences in readings between the two editions due to grammatical or syntactic inconsistencies in the autograph, where one publisher clearly decided to present the original faithfully despite obvious syntactic ambiguities, while the other intervened in the text. What follows are some examples of such differences in readings between the two editions.

Example 1. In the autograph, on $\mathrm{f} .107 \mathrm{v}$, in the sentence Hic saltus simili modo atque Lucauiza e Scardo instar promontorii protensum est ex Orbello in ortum... ("This gorge, similarly to Lukavica from Skard, extends like a branch from Orbel towards the east..."), ${ }^{30}$ the participle protensum, which is part of the predicate, should agree with its subject hic saltus; therefore, it should read protensus. Szalay resolves this lapsus calami from the original with the correct protensus, ${ }^{31}$ while Fortis leaves the form protensum. ${ }^{32}$

Example 2. There are also reverse examples, when Fortis intervenes in the text and Szalay preserves the original from Vrančić's autograph, like the one in the sentence on f. 89: Accesserat, quod et pauimenta eius altius quam pro urbana mundicie et conditione temporis adeo erat luto obrutus ac fedatus... ("This was also due to the fact that its sidewalk, more than what would correspond to the city order and weather conditions, was covered with mud and dirtied..." $).{ }^{33}$ Fortis replaced pavimenta with pavimentum here, and the participles obrutus and fedatus with the forms obrutum and foedatum. ${ }^{34}$

\footnotetext{
${ }^{25}$ Fortis, Viaggio, XXXIII.

26 MHH 1 (= II), 318.

27 HU-OSZK-Fol. Lat. 422, II, fol. 94v.

28 Fortis, Viaggio, XLIV.

29 MHH 1 (= II), 330.

30 HU-OSZK-Fol. Lat. 2380, III, fol. 107v.

31 MHH 1 (= II), 311.

32 Fortis, Viaggio, XXVII.

33 HU-OSZK-Fol. Lat. 422, II, fol. 89.

34 Fortis, Viaggio, XL; MHH 1 (= II), 326.
} 
As for other deviations from the autograph, the most numerous are omissions, of which there are seventeen in the Fortis edition and eleven in Szalay's. Larger lacunae have also been found in both editions, such as:

\begin{tabular}{|c|c|c|c|}
\hline autograph & A. Fortis & autograph & L. Szalay \\
\hline $\begin{array}{c}\text { instituerat, pudore } \\
\text { forsan ductus, } \\
\text { quod destiterat, } \\
\text { circumuehitur }^{35}\end{array}$ & $\begin{array}{c}\text { instituerat, } \\
\text { circumvehitur }^{36}\end{array}$ & $\begin{array}{c}\text { Zuha Clyszura, merito et } \\
\text { Bulgaris, etiam Rascianis } \\
\text { Zuha Clyszura }\end{array}$ & Zuha Clyszura \\
\hline
\end{tabular}

In terms of frequency, these are followed by inversions - there are thirteen examples in Fortis and one in Szalay. The least numerous are additions, six of them in Fortis, and none in Szalay. The following table shows the statistical data regarding the discrepancies between the autograph and the editions:

\begin{tabular}{|c|c|c|}
\hline & ed. A. Fortis & ed. L. Szalay \\
\hline differences in readings & 89 & 65 \\
\hline additions & 6 & 0 \\
\hline omissions & 17 & 11 \\
\hline inversions & 13 & 1 \\
\hline
\end{tabular}

\section{Conclusion}

The textual transmission of Vrančić's travelogue was certainly lively, as confirmed by the existence of one autograph and three transcripts (although part of the introduction has been omitted and part has been retold), as well as two complete and one fragmentary published editions. A philological comparison of Vrančićs autograph and the manuscripts of Mrnavić's De Illyrico Caesaribusque Illyricis, which quotes most of Vrančićs text in the second book, shows that all three copies are prevalently consistent in terms of different readings, additions, omissions, and inversions. Still, the closest to Vrančić's autograph is the Dubrovnik manuscript, as it contains fewer deviations from the original (primarily in terms of different readings) compared to the Zagreb and Sarajevo manuscripts. The correct readings, which are consistent in the Dubrovnik copy and in Vrančićs autograph, and the deviations we find in the same places in the Zagreb and Sarajevo copies indicate that the Dubrovnik transcriber either used another template in which Vrančić's text was more accurately transcribed, or he was more

\footnotetext{
35 HU-OSZK-Fol. Lat. 2380, III, fol. 105v.

${ }^{36}$ Fortis, Viaggio, XXV.

37 HU-OSZK-Fol. Lat. 2380, III, fol. 108.

38 MHH 1 (= II), 312.
} 
careful in his transcription in relation to the Zagreb and Sarajevo transcribers, provided that the assumption that all three transcripts were based on the same source is correct. It should be pointed out that these conclusions are based solely on the comparison of that part of the manuscript in which Vrančićs text was transcribed, and that it would certainly be necessary to compare other parts of the three transcripts in detail in order to obtain additional confirmation. The differences in the readings between Vrančićs autograph and the transcripts of the travelogue show that these are not always a result of the transcribers' negligence, but occasionally of their effort to correct Vrančić's mistakes. Thus, Mysia from Vrančićs autograph, which generally refers to the ancient province on the Balkan Peninsula south of the lower Danube and the lower course of the Sava and east of the Drina, is consistently transcribed in all three transcripts as Maesia / Męsia (or Moesia), and the name of its inhabitants Mysi as Maesi / Męsi. The transcribers repeatedly intervened when they found grammatical inconsistencies in the autograph, for example in the sentence Addito illi etiam lacu in medio, quum nos ne ipsum quidem conspeximus, tanta siccitate exaruerat, ${ }^{39}$ where the word quum from the autograph is replaced by the correct form quem. Deviations from the autograph in terms of additions, omissions, and inversions are mostly consistent in all three transcripts, but they are the most numerous in the Zagreb copy. Furthermore, some lacunae can be found in the Dubrovnik manuscript that are not present in the Zagreb or Sarajevo copies. Such deviations are mostly the result of mistakes made by the transcriber.

As for the editions, the statistics based on comparing the autograph with the Fortis and Szalay editions favour the Hungarian edition, i.e. they confirm that it is certainly the Szalay edition that the readers and researchers of Vrančićs text can rely on with greater confidence. However, the fact that this edition also contains a large number of deviations from the autograph, that it was printed more than 160 years ago, and that it is not equipped with a critical apparatus indicates that there is a need to re-edit Vrančićs travelogue according to modern philological standards. The importance of this venture is self-evident if we take into account that the Iter Buda Hadrianopolim is a first-hand report in which Antun Vrančić documented his first diplomatic trip to Constantinople and that it is the only travelogue preserved in his literary legacy.

${ }^{39}$ HU-OSZK-Fol. Lat. 422, II, fol. 78v. 


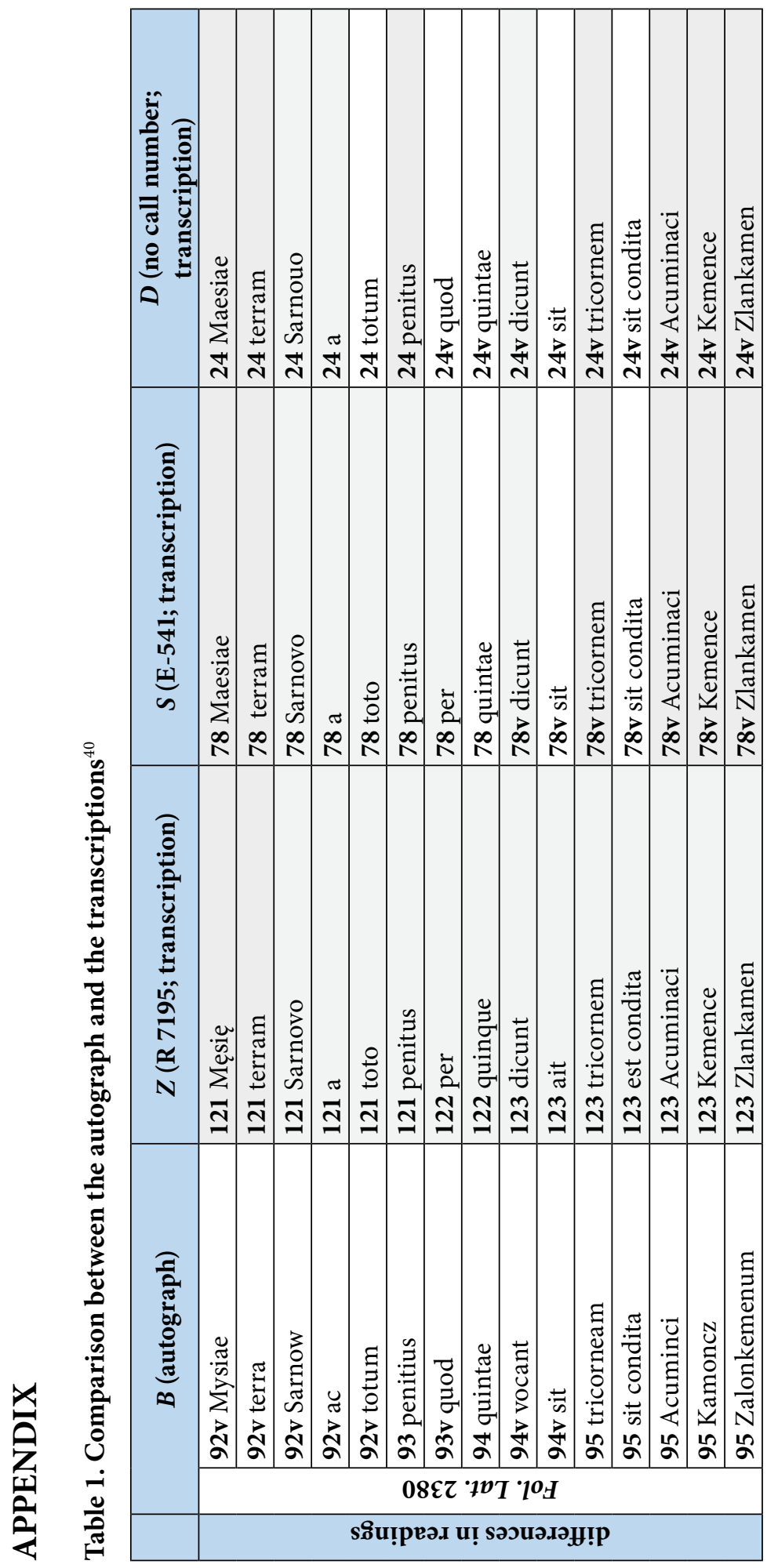

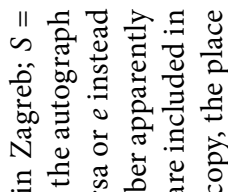

तี

至

.

昰寻

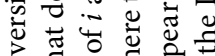

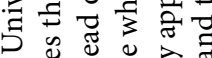

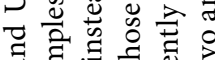

ส

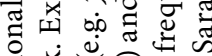

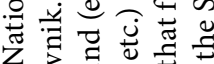

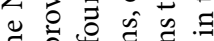

\pm च

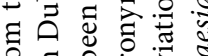

요용

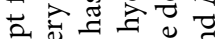

जै

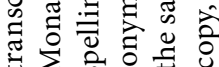

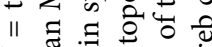

$N$ 娄

ثे प्च घै

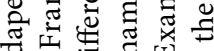

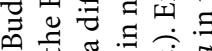

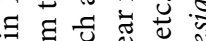

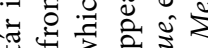

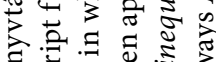

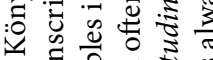

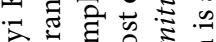

岛 पु 0 氖志

N 0 吾

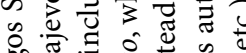

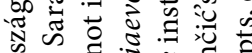

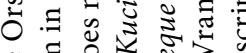

‡ छ

ป

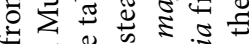

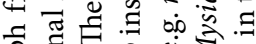

ते :

क०

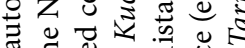
क I

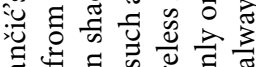

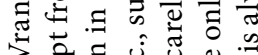

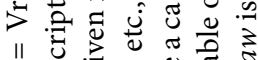
11

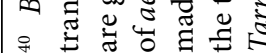




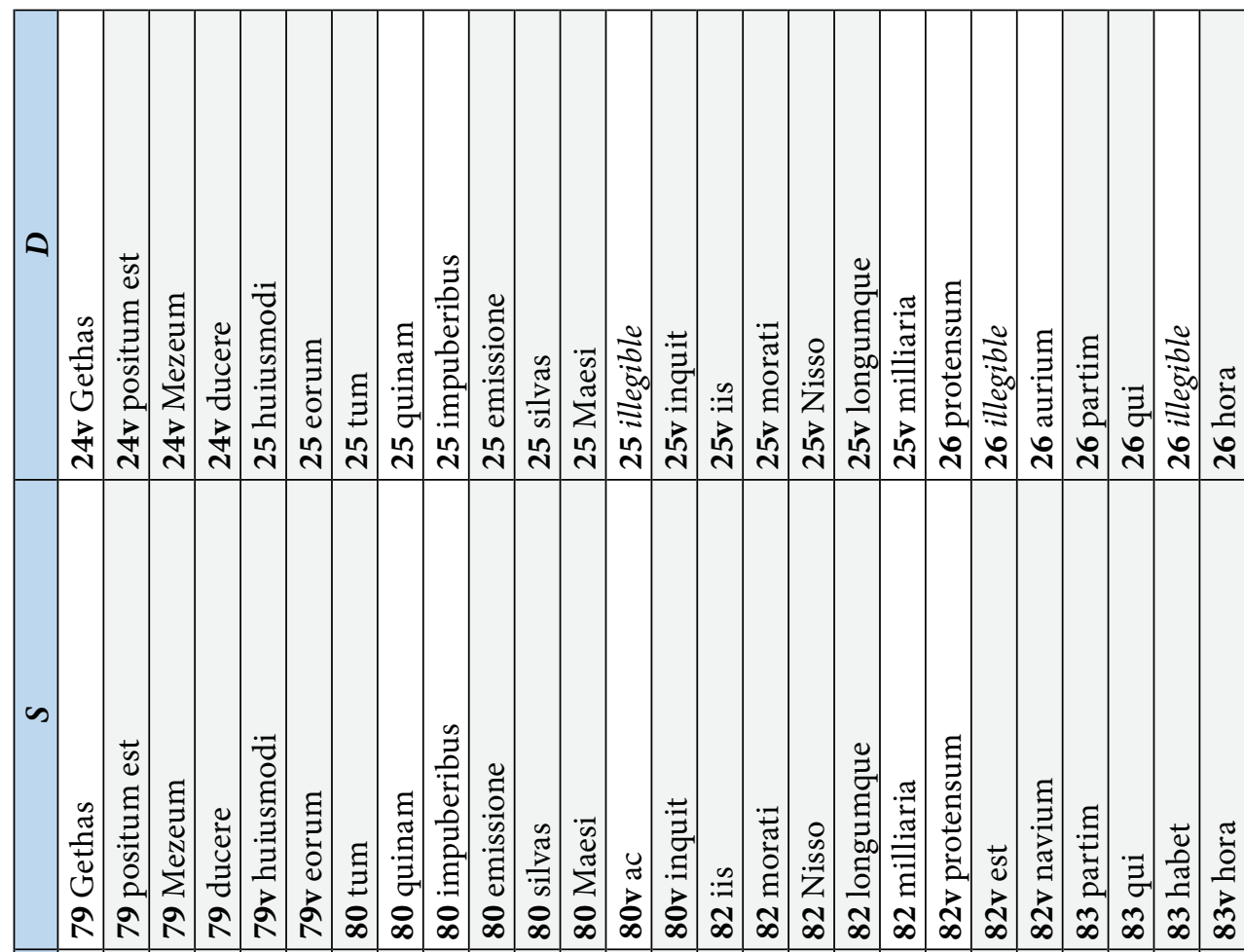

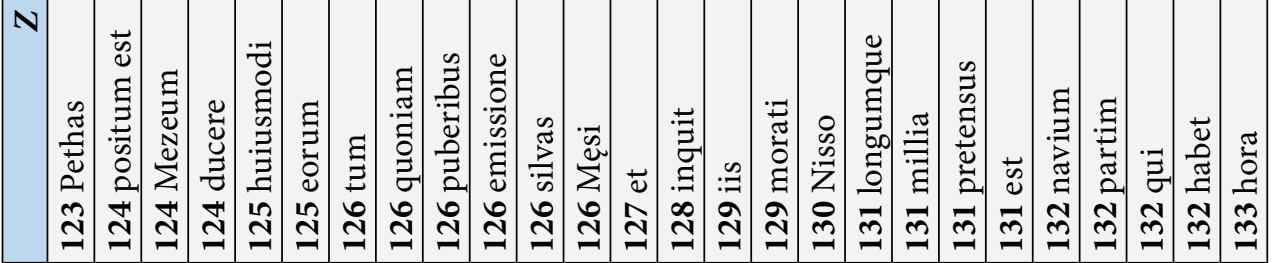

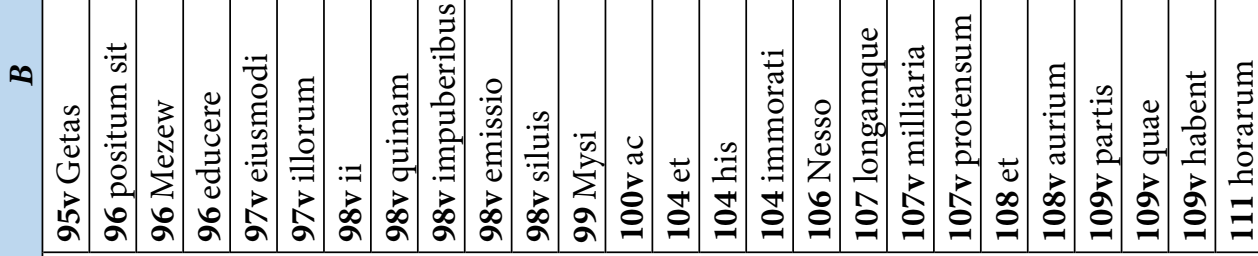

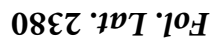




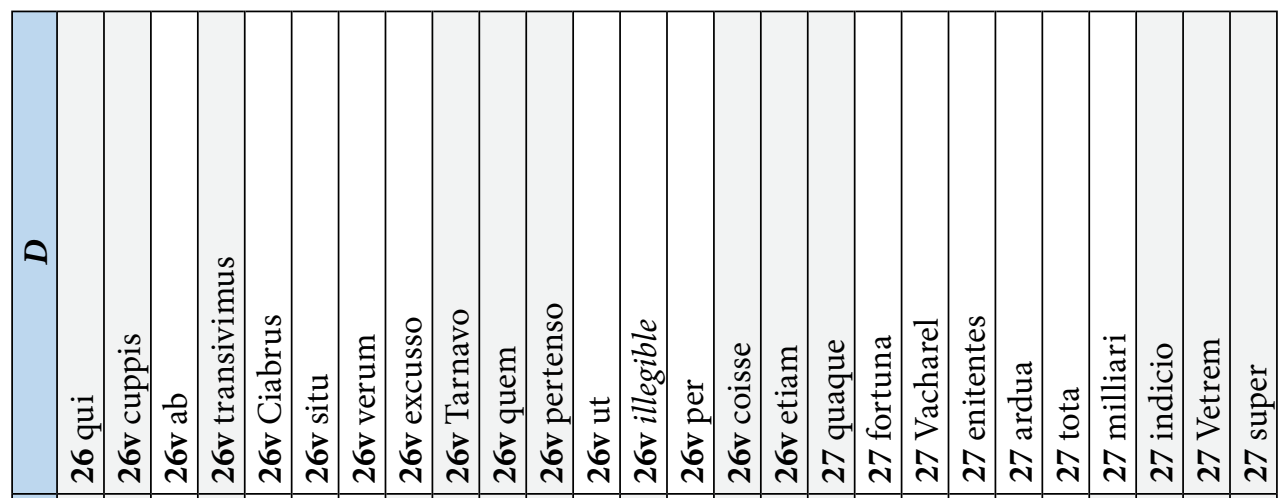

$\infty$

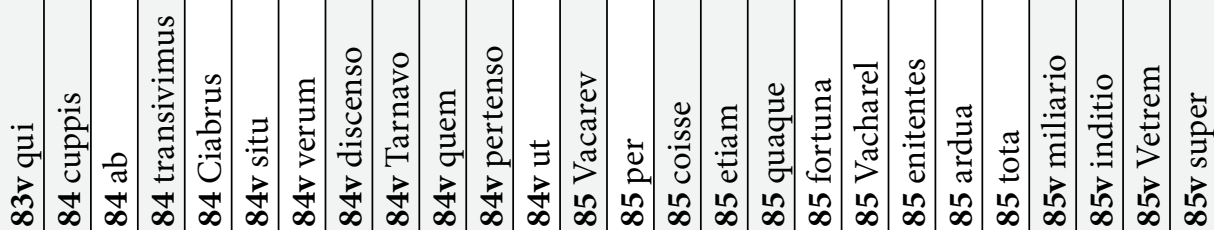

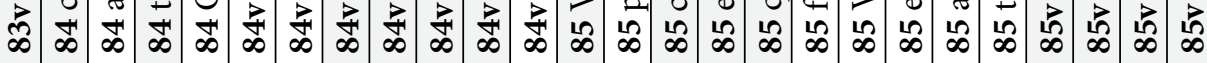

$\mathbf{N}$

$\stackrel{\infty}{\Xi}$

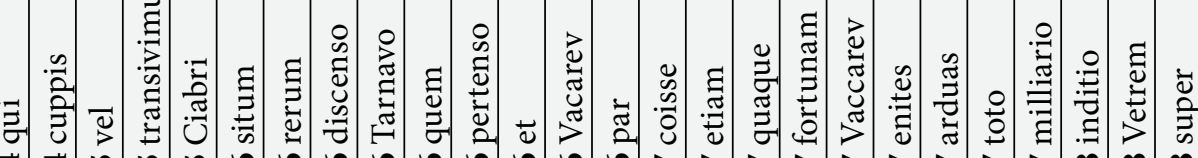

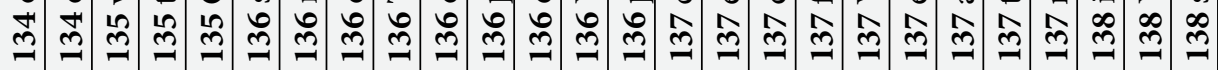

$\infty$

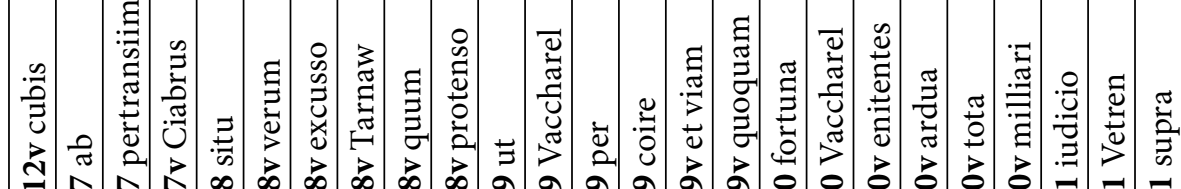

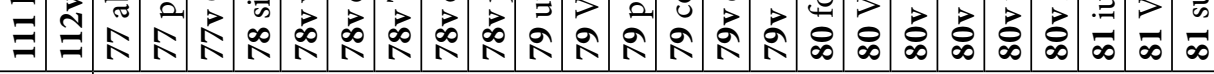




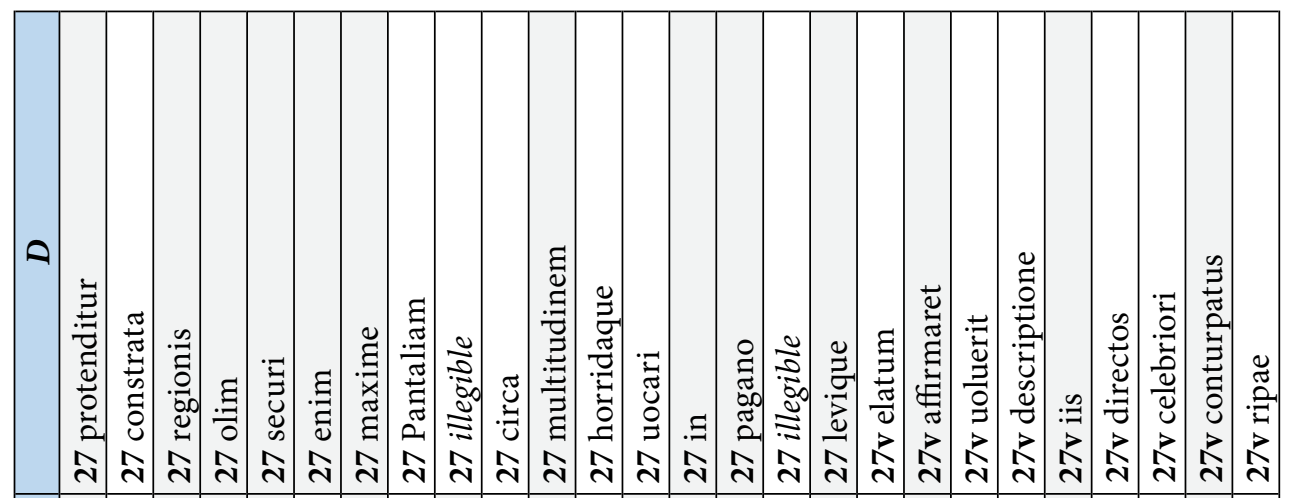

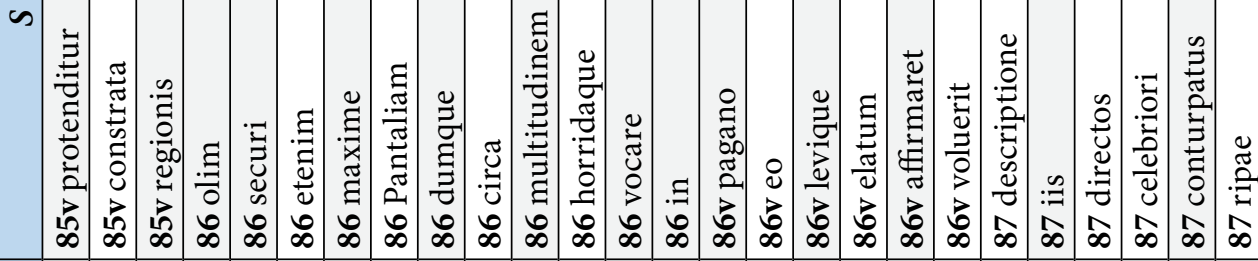

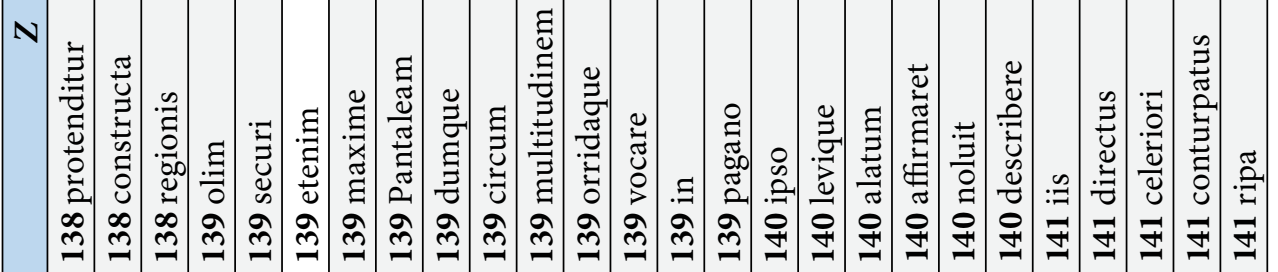

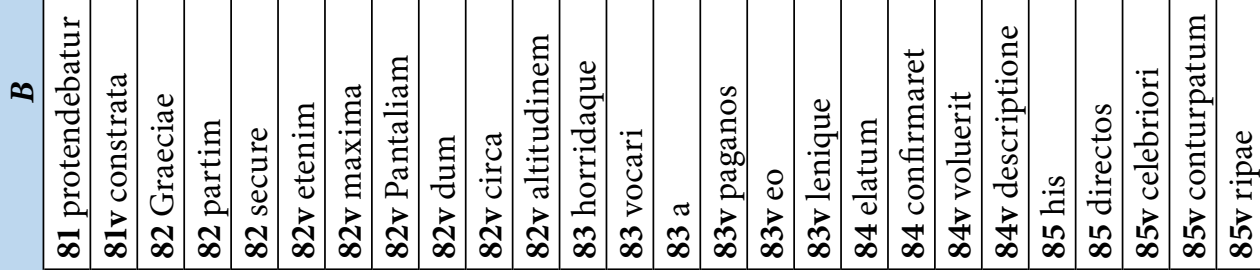
zъ† $\cdot 7 v_{T} \cdot 10_{H}$ 

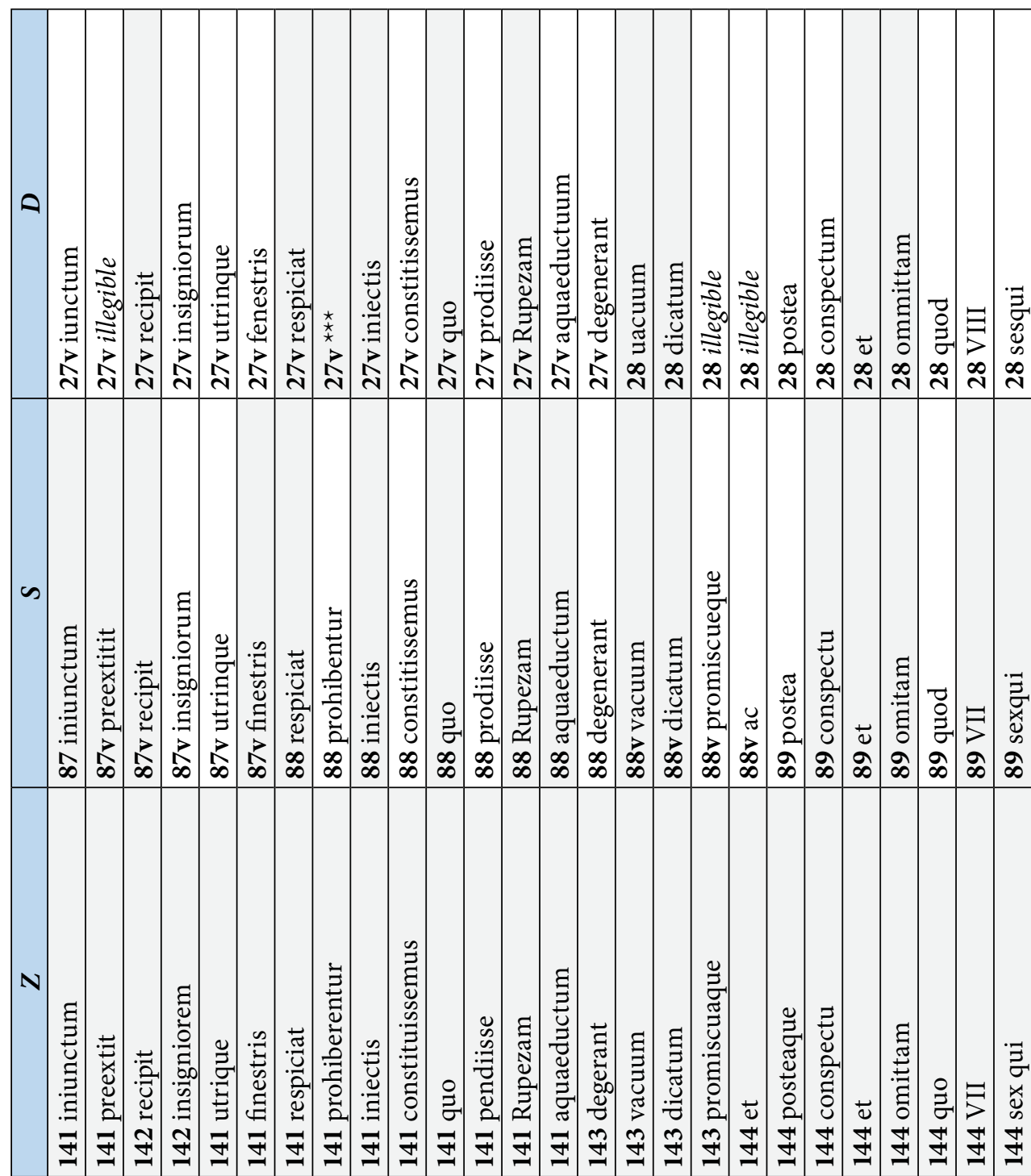

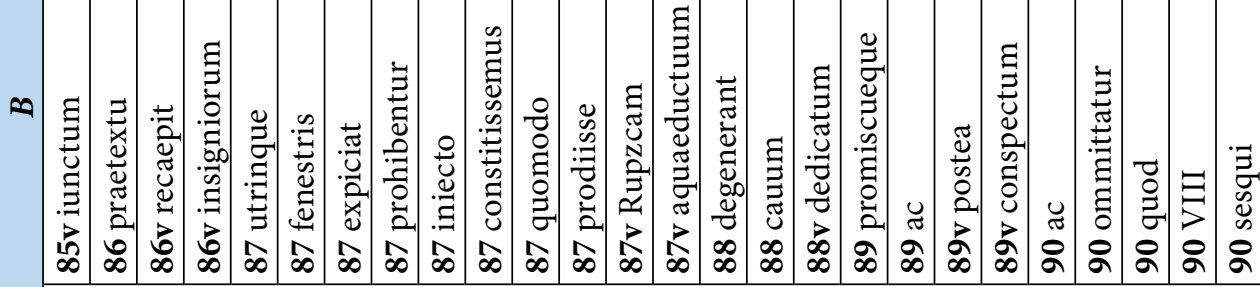
zъ॰ $7 v_{T} \cdot 10_{H}$ 


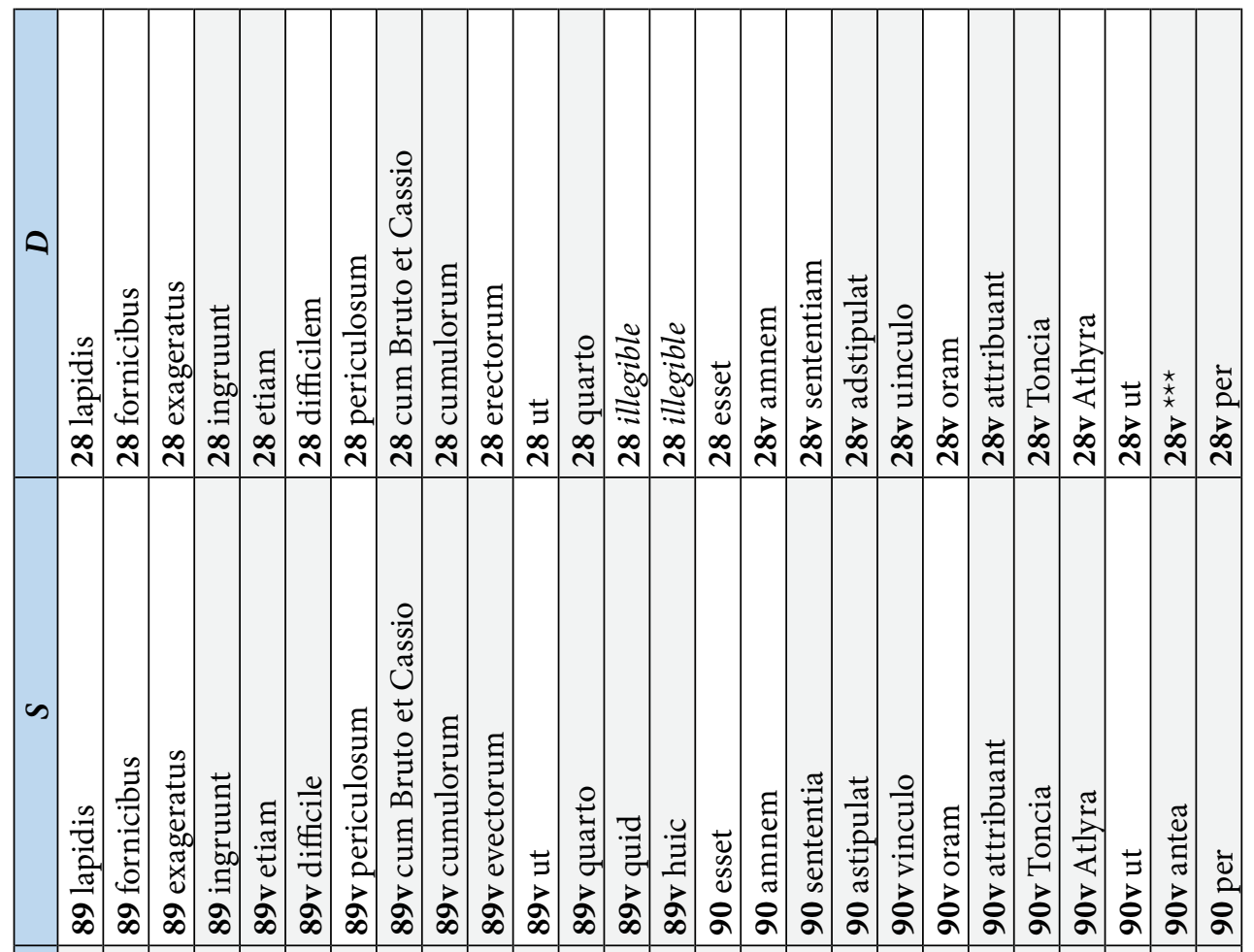

N

$\cdot \frac{0}{\infty}$

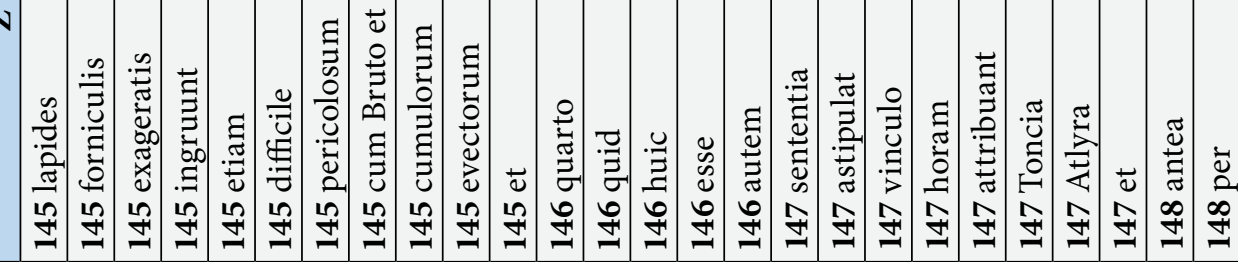

웅

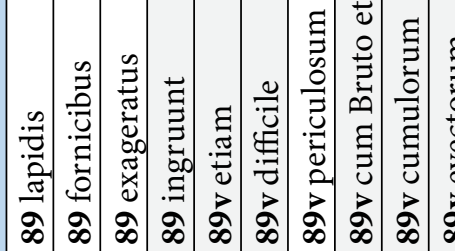

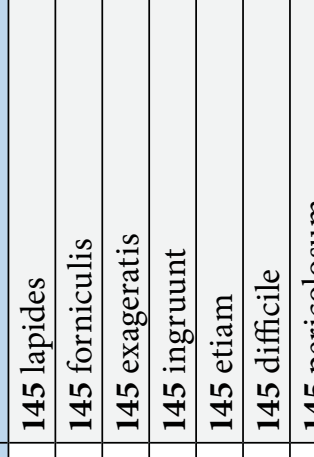




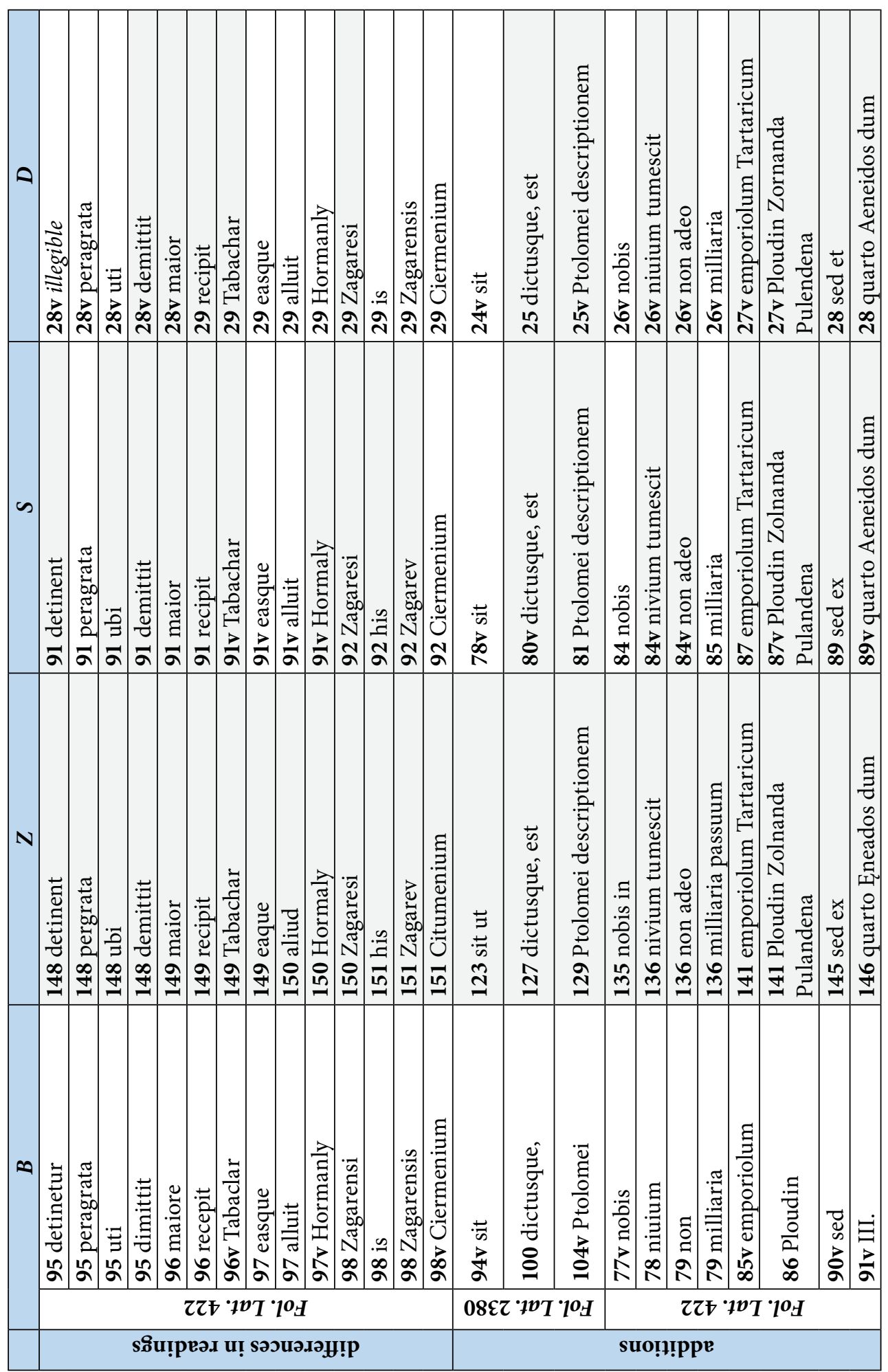




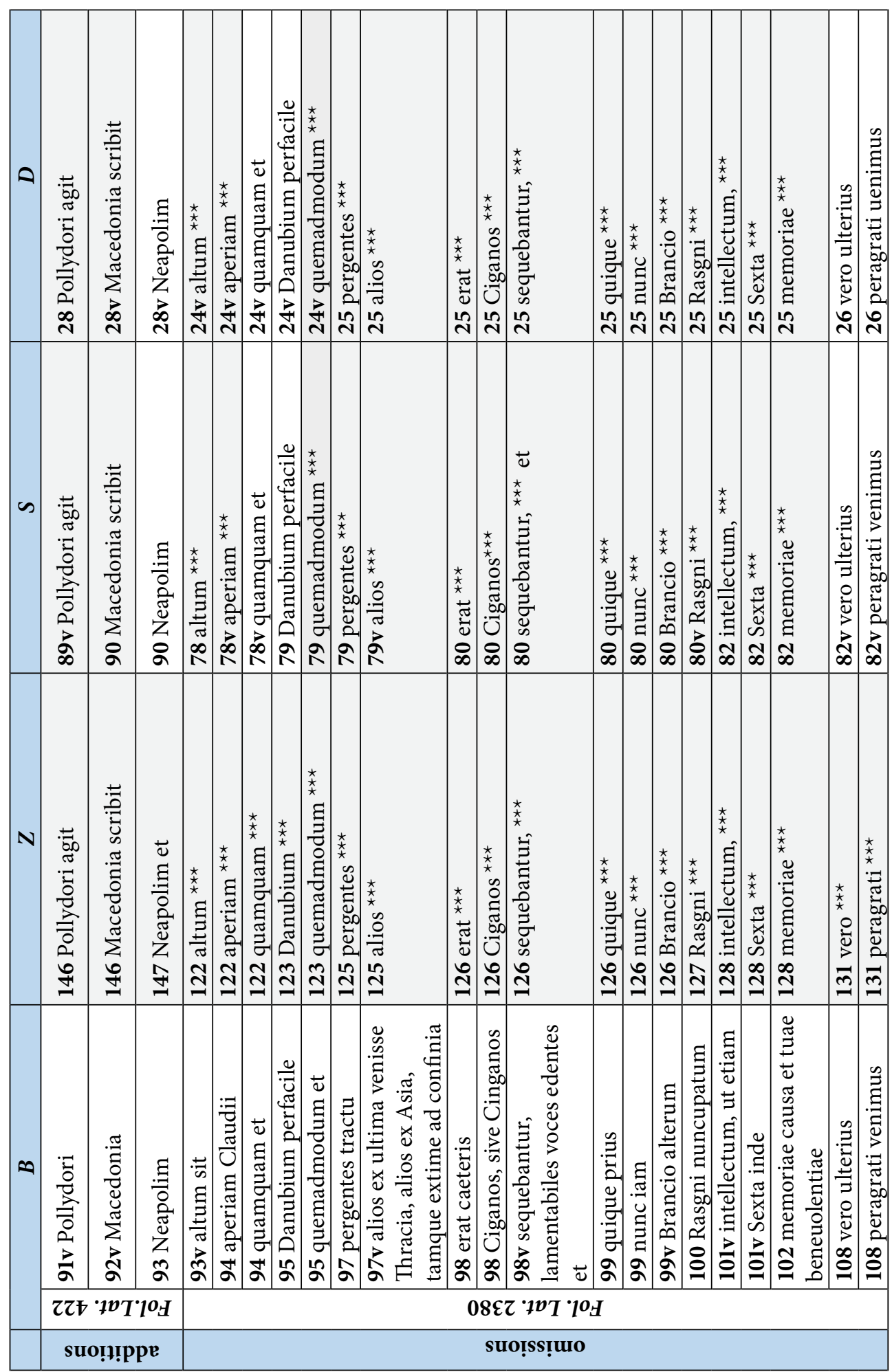




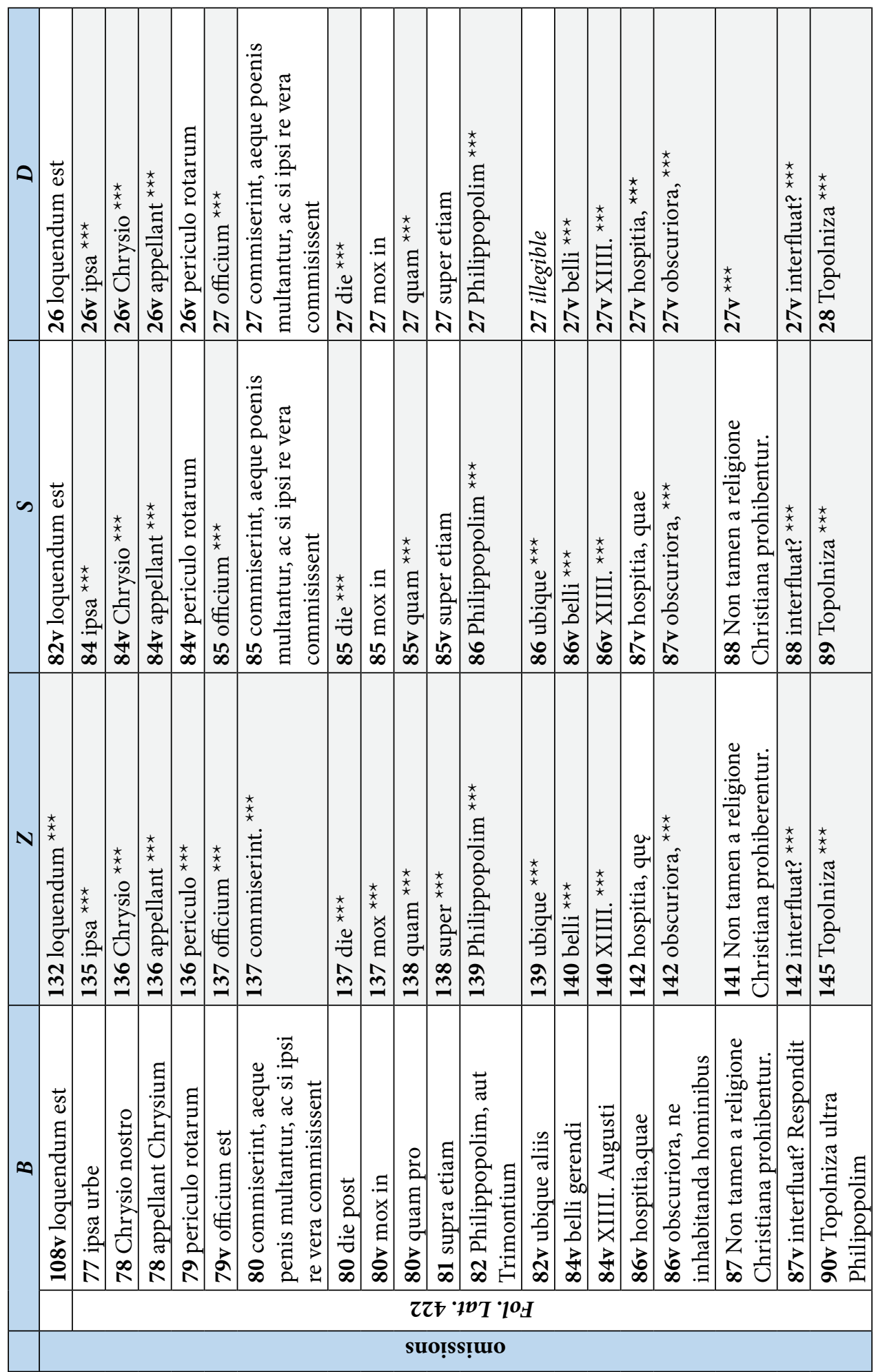




\begin{tabular}{|c|c|c|c|c|c|c|c|c|c|c|c|c|c|}
\hline$\theta$ & 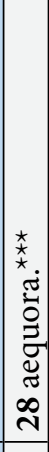 & 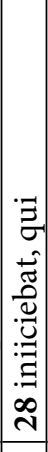 & 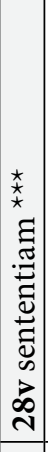 & 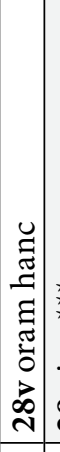 & 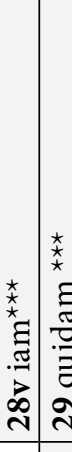 & 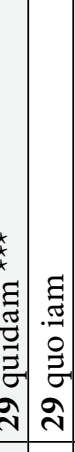 & 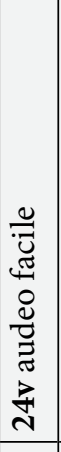 & 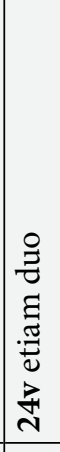 & 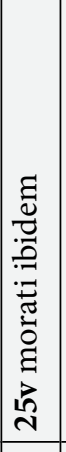 & 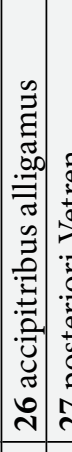 & 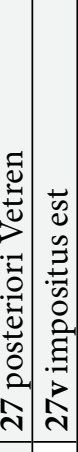 & 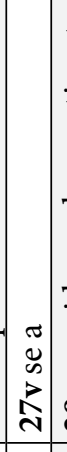 & 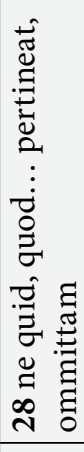 \\
\hline$\infty$ & 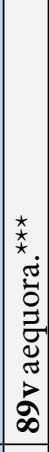 & 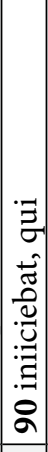 & 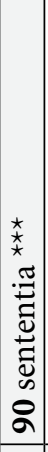 & 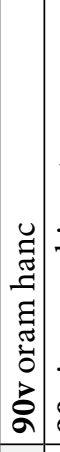 & 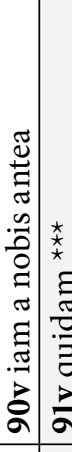 & 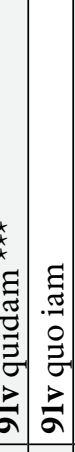 & 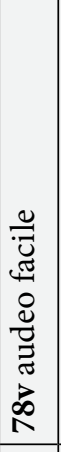 & 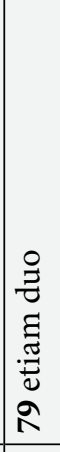 & 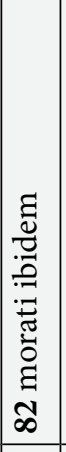 & 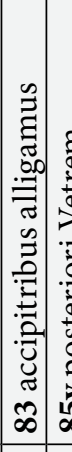 & 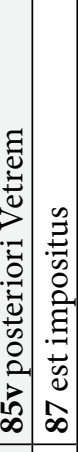 & 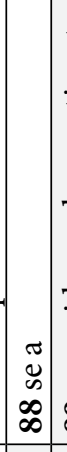 & 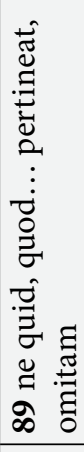 \\
\hline $\mathbf{N}$ & 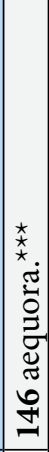 & 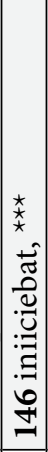 & 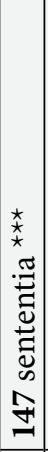 & 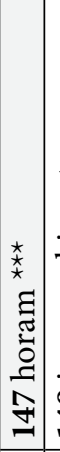 & 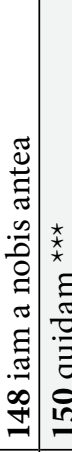 & 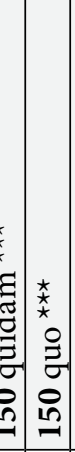 & 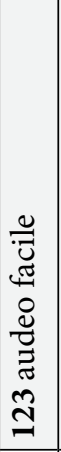 & 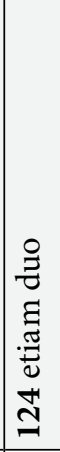 & 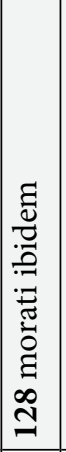 & 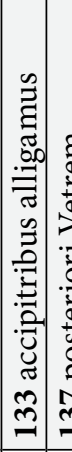 & 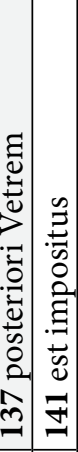 & 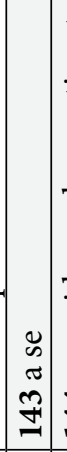 & 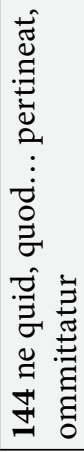 \\
\hline$\infty$ & 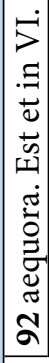 & 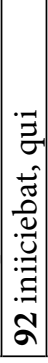 & 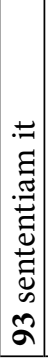 & 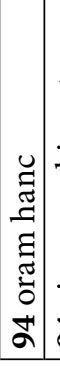 & 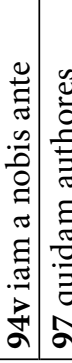 & 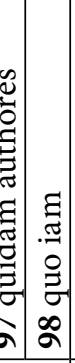 & 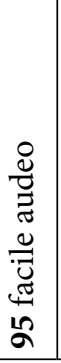 & 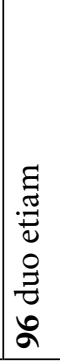 & 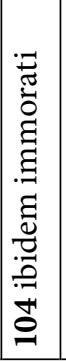 & 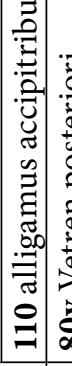 & 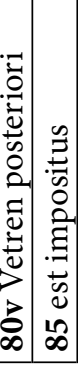 & 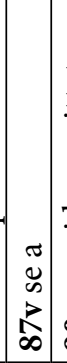 & 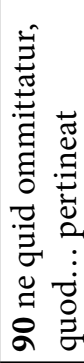 \\
\hline & \multicolumn{6}{|c|}{$z そ \mp \cdot 1 v_{T} \cdot 10_{H}$} & \multicolumn{4}{|c|}{$08 \varepsilon z \cdot 10 T \cdot 10_{H}$} & \multicolumn{3}{|c|}{$z Z \ni \cdot 10 T \cdot 10_{H}$} \\
\hline & \multicolumn{6}{|c|}{ suo!̣ss!̣uo } & \multicolumn{7}{|c|}{ SUO!̣..əАU! } \\
\hline
\end{tabular}




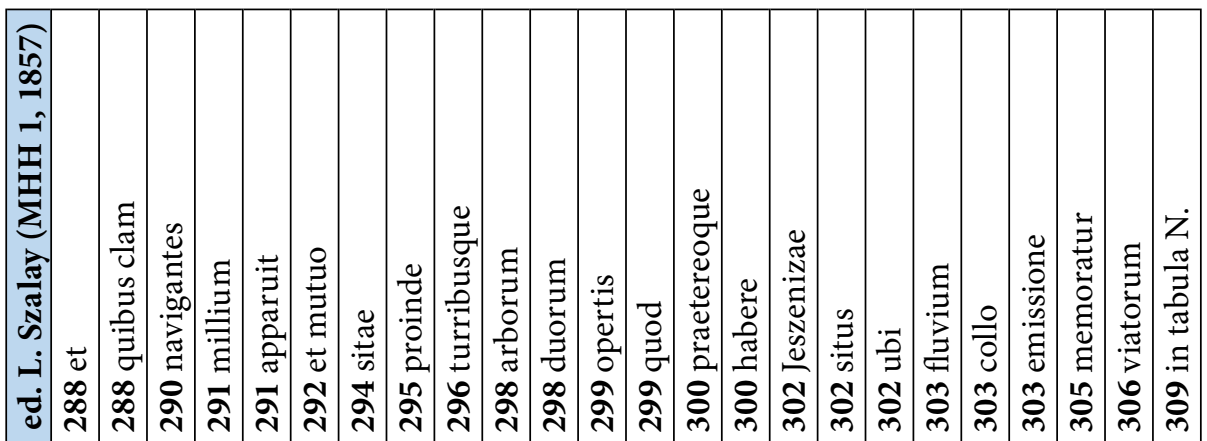

로을

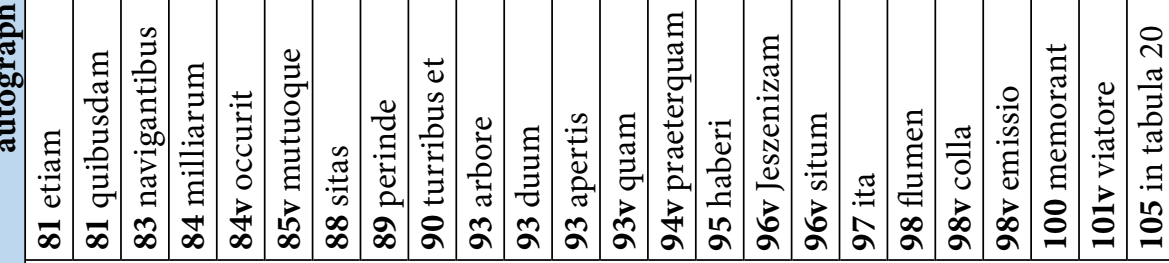
$08 \varepsilon z \cdot 7 v^{\top} \cdot 10^{\circ}$

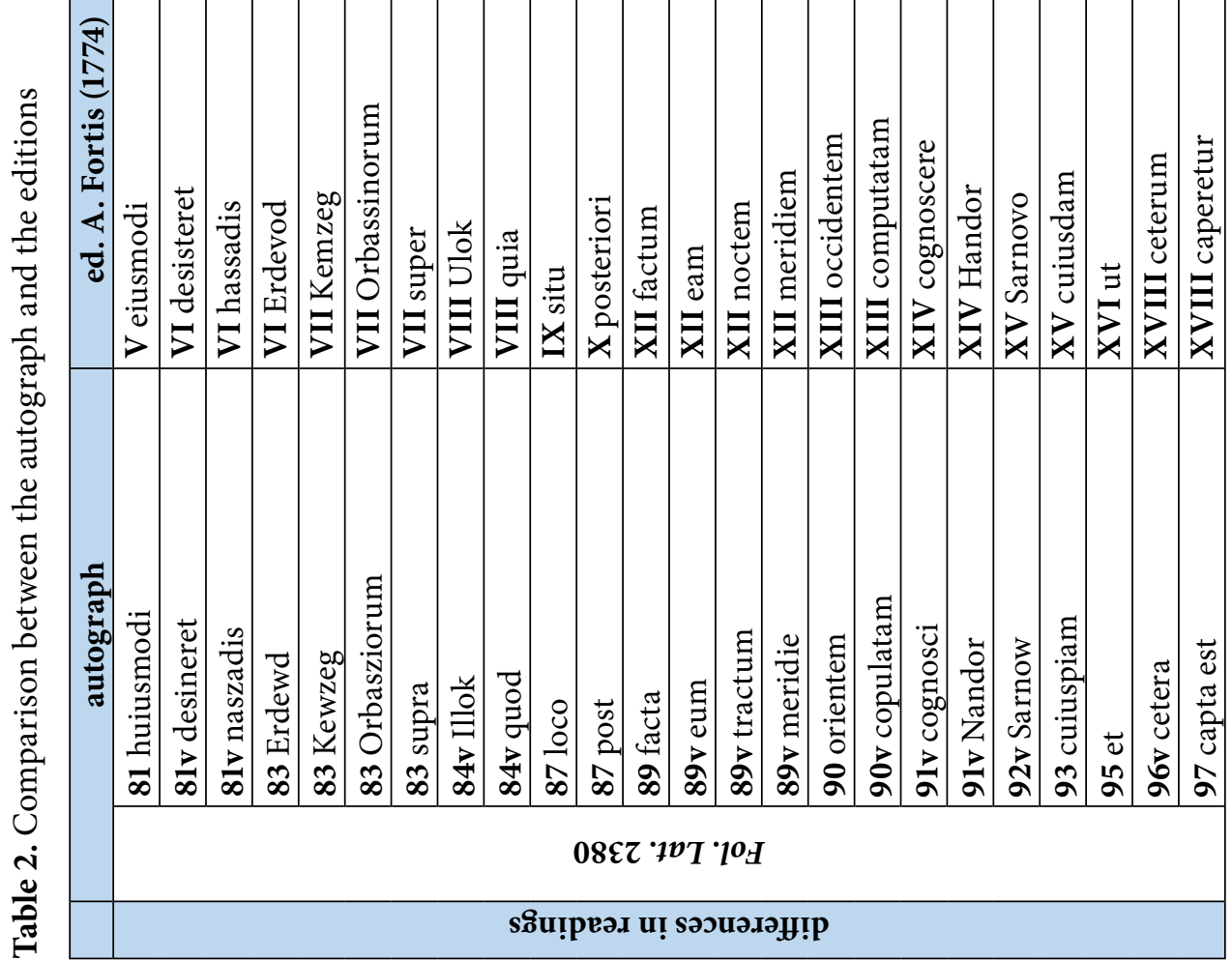




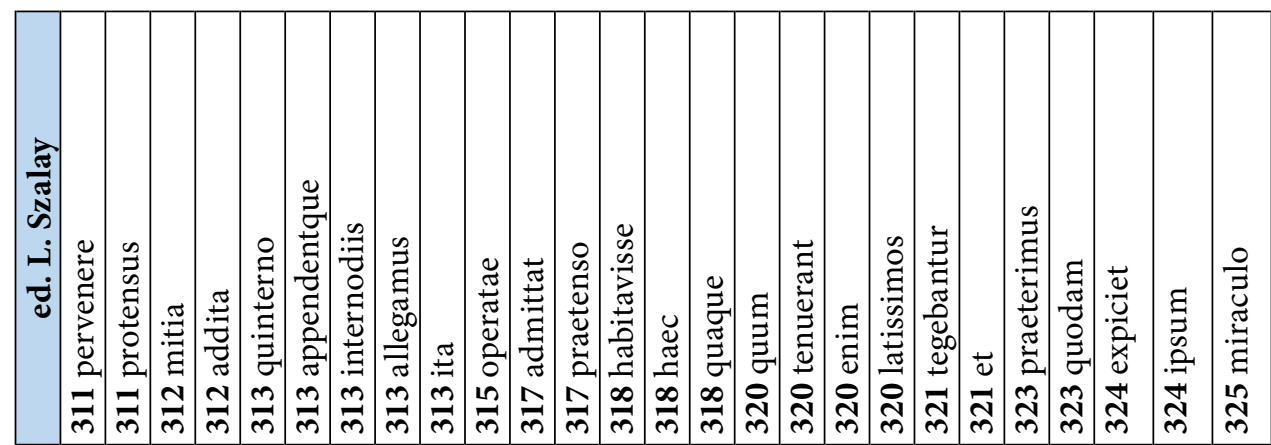

:

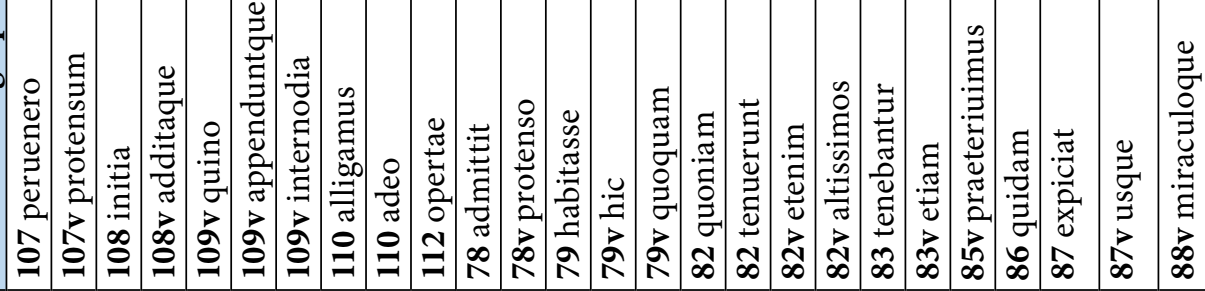

$08 \varepsilon z \cdot 707 \cdot 10_{H}$

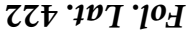

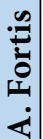

$\dot{\mathrm{s}}$

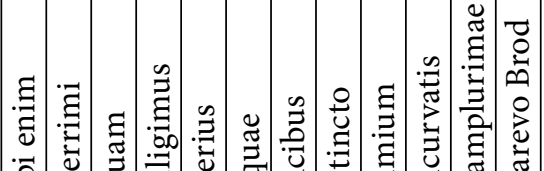

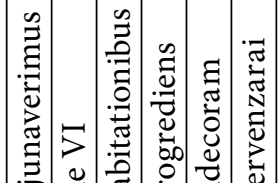

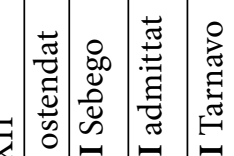

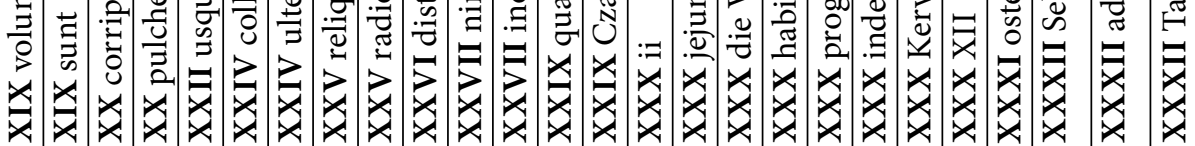

호ำ

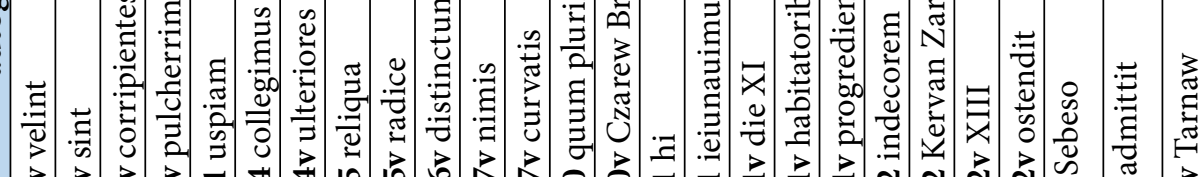

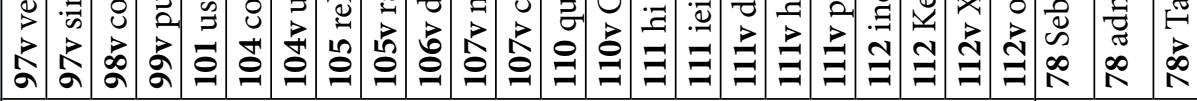

$08 \varepsilon z \cdot 1 v^{\top} \cdot 10_{H}$

$\cdot 7 v_{T} \cdot 10_{H}$ 


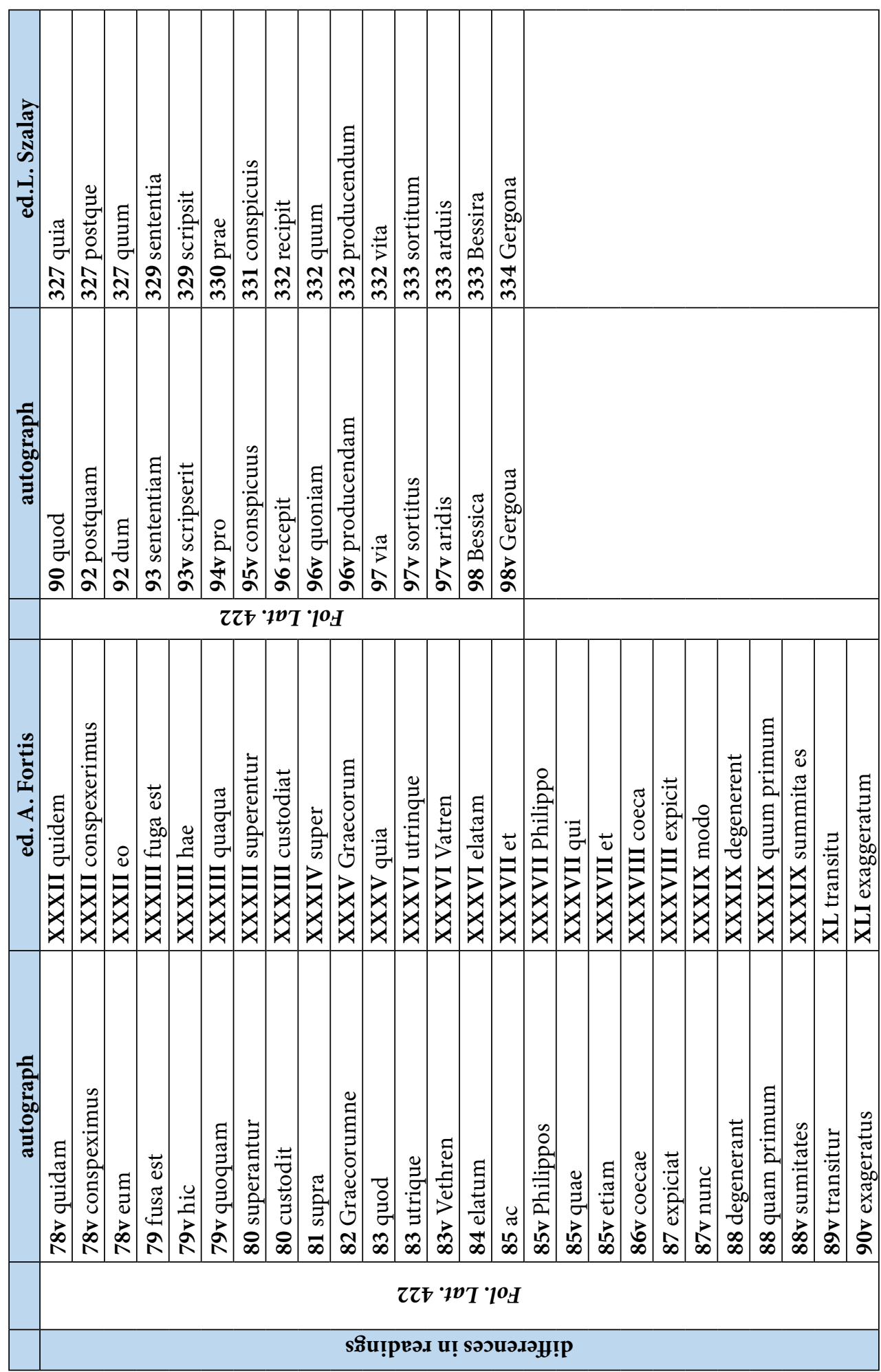




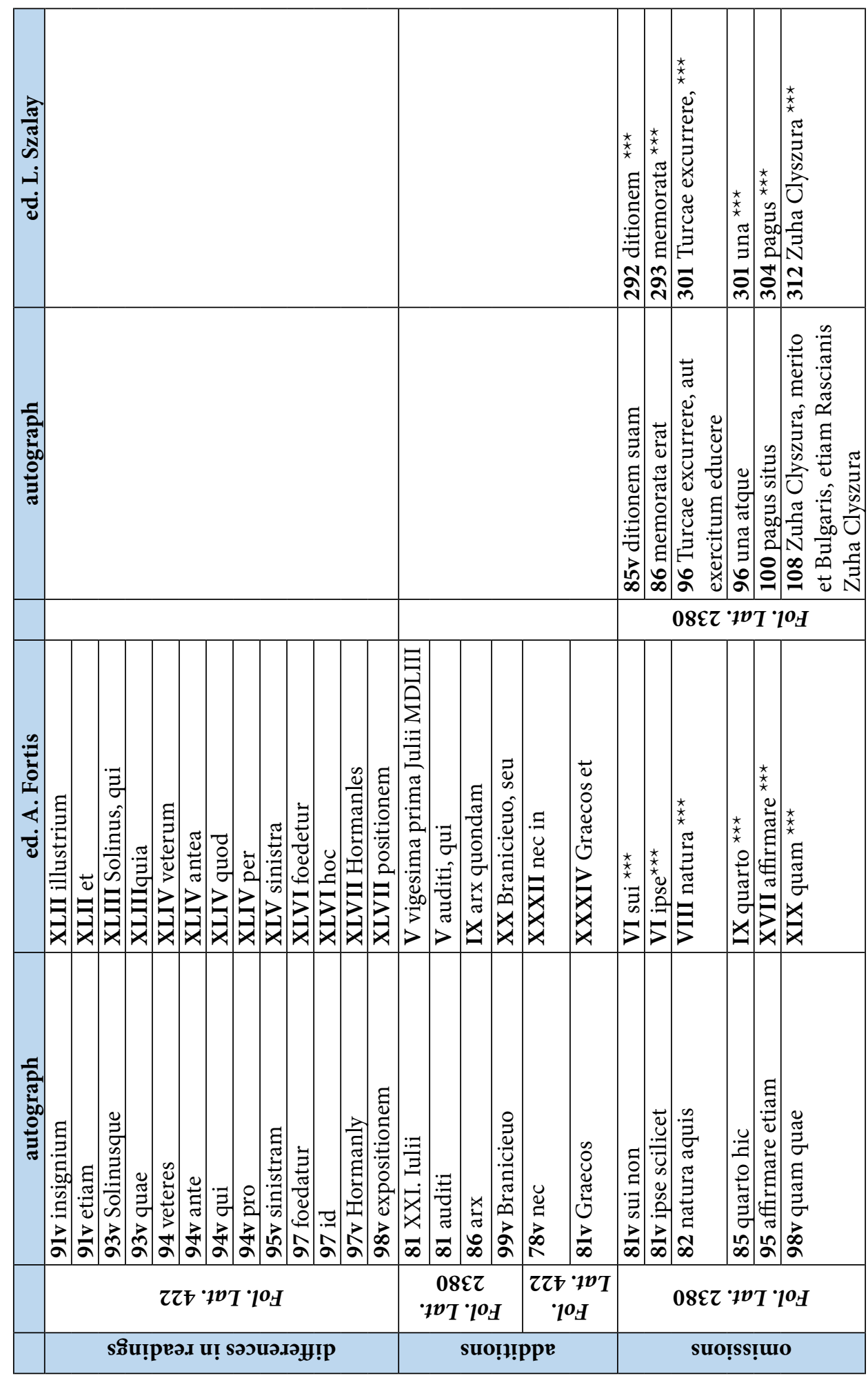




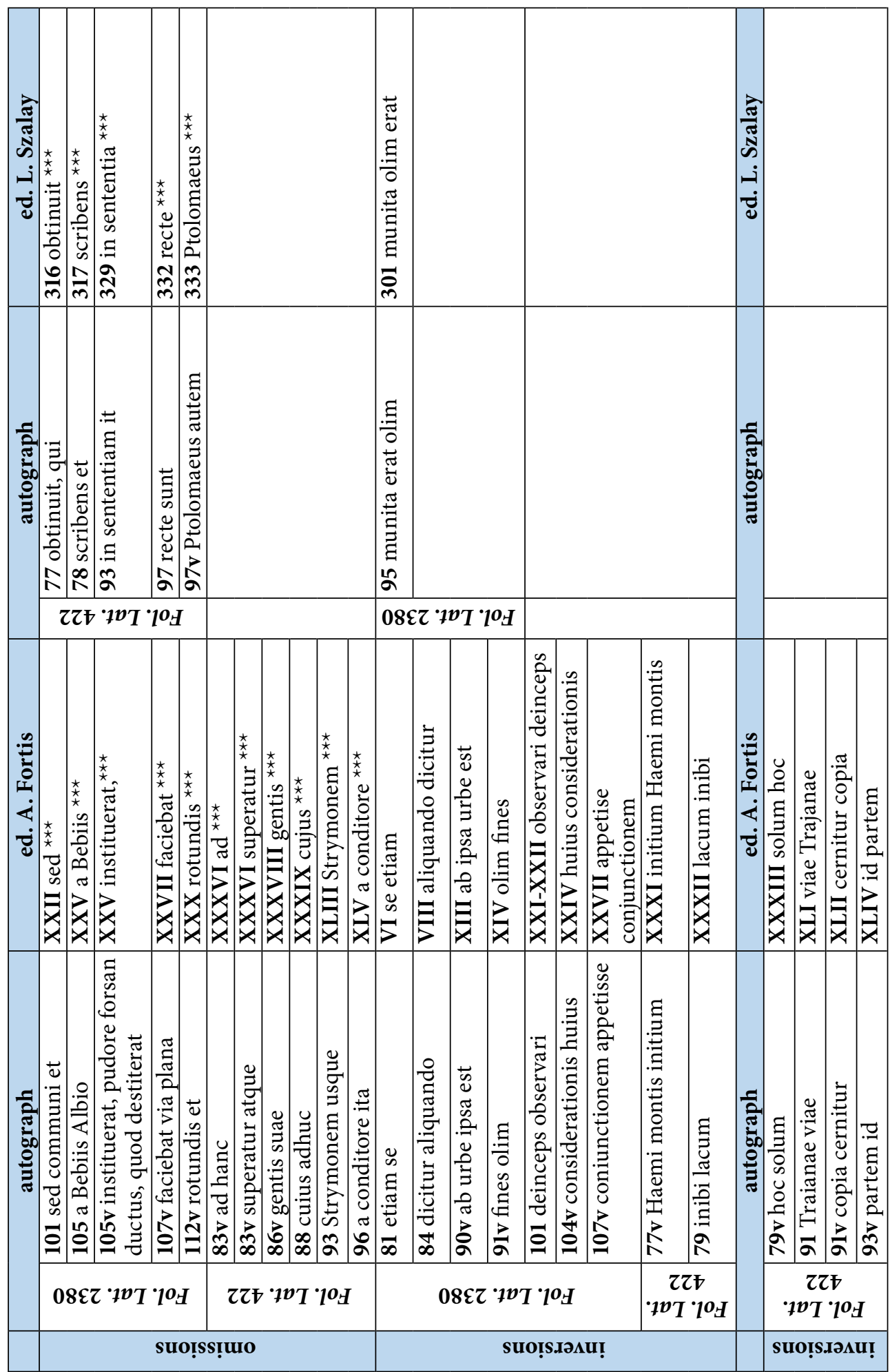




\section{Unpublished sources}

Hrvatska - Nacionalna i sveučilišna knjižnica u Zagrebu - R 7195 (HR-NSK-R 7195)

Hungary - Országos Széchényi Könyvtár, Budapest - Fol. Lat. 2380 (HU-OSZKFol. Lat. 2380)

Hungary - Országos Széchényi Könyvtár, Budapest - Fol. Lat. 422 (HU-OSZKFol. Lat. 422)

\section{Published Sources and Literature}

Birnbaum, Marianna Daisy. Croatian and Hungarian Latinity in the Sixteenth Century. Zagreb-Dubrovnik: Most, 1993.

Blažević, Zrinka; Vlašić, Anđelko, eds. Carigradska pisma Antuna Vrančića: hrvatski $i$ engleski prijevod odabranih latinskih pisama. Zagreb-Istanbul: Oğuz Aydemir, 2018.

Demo, Šime; Manea-Grgin, Castilia, eds. Antun Vrančić. Historiografski fragmenti. Šibenik: Gradska knjižnica "Juraj Šižgorić”, 2014.

Fortis, Alberto. Viaggio in Dalmazia, I-II. Venezia: Alvise Milocco all'Apolline, 1774 .

Galvani, Federico Antonio. Il re d'armi di Sebenico con illustrazioni storiche, I. Venezia: Prem. Stabil. Tip. di Pietro Naratovich, 1884.

Gyulai, Éva. “Antonius Verantius”. In: Christian-Muslim Relations: A Bibliographical History, volume 7, edited by David Thomas et al., 362-371. Leiden: Brill, 2015.

Koller, József, ed. Historia episcopatus Quinqueecclesiensis, V. Posonii et Pestini: Sumptibus Joannis Michaelis Landerer, 1782-1784.

Kukuljević Sakcinski, Ivan. Glasoviti Hrvati prošlih vjekova. Niz životopisâ. Zagreb: Naklada Matice hrvatske, 1886.

Lučin, Bratislav. "Antun Vrančić i Monumentum Ancyranum". Prilozi povijesti umjetnosti u Dalmaciji 45 (2019), no. 1: 219-251.

Ljubić, Šime. Dizionario biografico degli uomini illustri della Dalmazia. Vienna-Zara: Rod. Lechner; Battara e Abelich, 1856.

Matković, Petar. "Putovanja po balkanskom poluotoku XVI. vieka. Putovanje A. Vrančića g. 1553. u Carigrad”. Rad JAZU 71 (1884), 1-60.

Novaković, Darko. Sentimentalni odgoj. Antun i Faust Vrančić. Šibenik: Gradska knjižnica “Juraj Šižgorić”, 1995. 
Novaković, Darko; Vratović, Vladimir. S visina sve. Antun Vrančić. Zagreb: Globus, 1979.

Sorić, Diana. "Klasifikacija pisama Antuna Vrančića". Colloquia Maruliana 18 (2009): 83-117.

Sorić, Diana; Serreqi Jurić, Teuta. "Literary Aspects of Antun Vrančičs Travelogue Iter Buda Hadrianopolim”. Živa Antika 68 (2018): 153-168.

Sorić, Diana; Serreqi Jurić, Teuta, eds. Antun Vrančić: Epistolae ad familiares. Zadar: Sveučilište u Zadru, 2020.

Stošić, Krsto. Galerija uglednih Šibenčana. Šibenik: Tiskara Kačić, 1936.

Szalay, László, ed. Verancsics Antal. Összes munkái, volume 1 (= Monumenta Hungariae historica. Scriptores II). Budapest: Eggenberger, 1857.

Tvrtković, Tamara. "Marko Marulić u djelu Ivana Tomka Mrnavića”. Colloquia Maruliana 16 (2007): 293-304.

Tvrtković, Tamara. Između znanosti i bajke - Ivan Tomko Mrnavić. Zagreb-Šibenik: Hrvatski institut za povijest; Gradska knjižnica “Juraj Šižgorić”, 2008.

Vrančić, Antun. "Putovanje iz Budima u Drinopolje”. In: Alberto Fortis, Put po Dalmaciji, edited by Josip Bratulić, translated by Mate Maras and Darko Novaković, 115-145. Split: Marjan tisak, 2004. 
Diana Sorić*

Teuta Serreqi Jurić ${ }^{* *}$

\section{Tekstualna transmisija putopisa Antuna Vrančića Iter Buda Hadrianopolim}

\section{Sažetak}

U sklopu književne produkcije hrvatskog humanista, diplomata i prelata Antuna Vrančića (1504. - 1573.) nalazi se putopis Iter Buda Hadrianopolim, koji je nastao kao svjedočanstvo Vrančićeve prve carigradske misije 1553.-1557. godine u koju je bio poslan po nalogu cara Ferdinanda I. (1503. - 1564.). Spis je sačuvan u autografu i u trima primjercima rukopisa u sklopu geografsko-historijskog djela De Illyrico Caesaribusque Illyricis hrvatskog humanista Ivana Tomka Mrnavića (1580. - 1637.) te je dvaput objavljen, u 18. i 19. stoljeću. U radu se na temelju saznanja do kojih su autorice došle radeći na pripremi kritičkog izdanja tog Vrančićeva teksta daje uvid u tekstualnu transmisiju djela Iter Buda Hadrianopolim. Filološka usporedba autografa i sačuvanih prijepisa daje odgovor na pitanje koji je primjerak najbliži Vrančićevu izvorniku, dok usporedba autografa i izdanja ukazuje na to kako je nedovoljna pouzdanost postojećih izdanja za jezično-stilske ili historiografske interpretacije zbog grešaka koje se u njima prenose i ugrožavaju čitanje teksta, uz nedostatak kritičkoga izdanja, dovoljan razlog za novu filološku obradu toga Vrančićeva djela prema načelima suvremene neolatinistike.

Ključne riječi: Antun Vrančić, Iter Buda Hadrianopolim, putopis, humanizam, tekstualna transmisija

Diana Sorić, Odjel za klasičnu filologiju, Sveučilište u Zadru, Obala kralja Petra Krešimira IV. 2, 23 000 Zadar, Republika Hrvatska, E-mail adresa: diana.soric@unizd.hr

** Teuta Serreqi Jurić, Odjel za klasičnu filologiju, Sveučilište u Zadru, Obala kralja Petra Krešimira IV. 2, 23000 Zadar, Republika Hrvatska, E-mail adresa: tserreqi@unizd.hr 